INTER NATIONAL MONETARY FUND
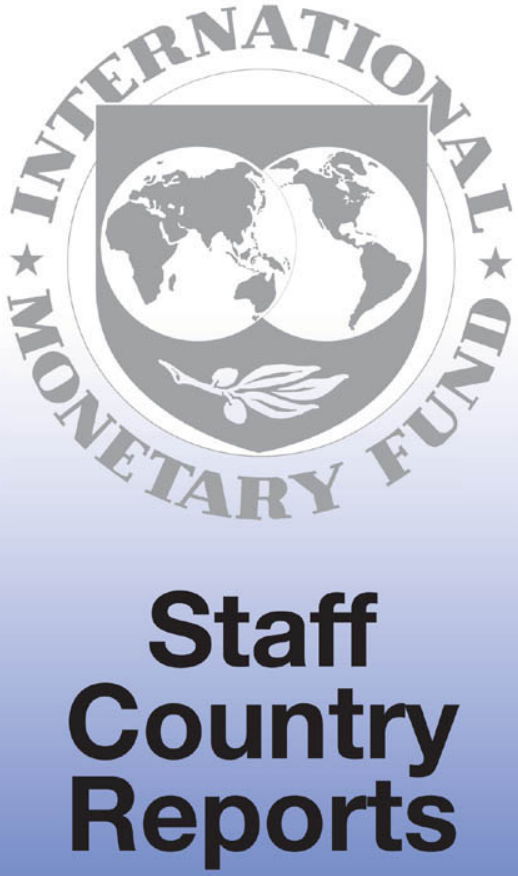


\title{
Belgium: 2008 Article IV Consultation—Staff Report; Staff Supplement; and Public Information Notice on the Executive Board Discussion
}

Under Article IV of the IMF's Articles of Agreement, the IMF holds bilateral discussions with members, usually every year. In the context of the 2008 Article IV consultation with Belgium, the following documents have been released and are included in this package:

- $\quad$ The staff report for the 2008 Article IV consultation, prepared by a staff team of the IMF, following discussions that ended on December 15, 2008, with the officials of Belgium on economic developments and policies. Based on information available at the time of these discussions, the staff report was completed on February 17, 2009. The views expressed in the staff report are those of the staff team and do not necessarily reflect the views of the Executive Board of the IMF.

- $\quad$ A staff supplement of March 2, 2009, updating information on recent developments.

- $\quad$ A Public Information Notice (PIN) summarizing the views of the Executive Board as expressed during its March 4, 2009 discussion of the staff report that concluded the Article IV consultation.

The policy of publication of staff reports and other documents allows for the deletion of market-sensitive information.

\author{
Copies of this report are available to the public from \\ International Monetary Fund • Publication Services \\ $70019^{\text {th }}$ Street, N.W. • Washington, D.C. 20431 \\ Telephone: (202) 623-7430 • Telefax: (202) 623-7201 \\ E-mail: publications@imf.org •Internet: http://www.imf.org
}

\section{International Monetary Fund \\ Washington, D.C.}


This page intentionally left blank 


\section{INTERNATIONAL MONETARY FUND}

\section{BELGIUM}

\section{Staff Report for the 2008 Article IV Consultation}

Prepared by Staff Representatives for the 2008 Consultation with Belgium

Approved by Ajai Chopra and Anthony Boote

February 17, 2009

Contents

Page

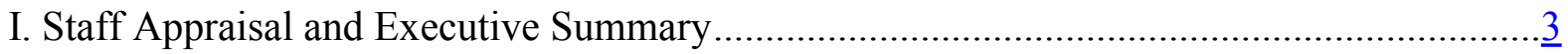

II. Current Crisis and Outlook...........................................................................................

A. Macroeconomic Outlook.................................................................................

B. Inflationary Effects of Commodity Price Shocks ..................................................... $\frac{8}{2}$

C. Competitiveness and the Real Effective Exchange Rate (REER).............................

D. The Financial Crisis and Macrofinancial Linkages.................................................10

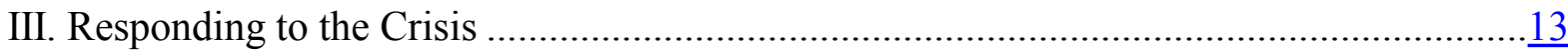

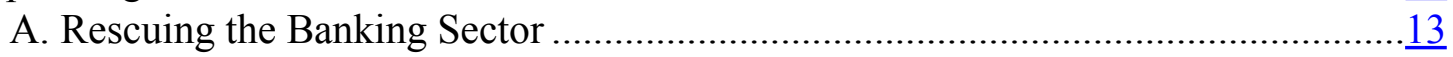

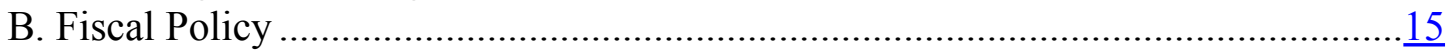

IV. Beyond the Crisis-Restoring Growth, Enhancing Resilience, and Returning Fiscal

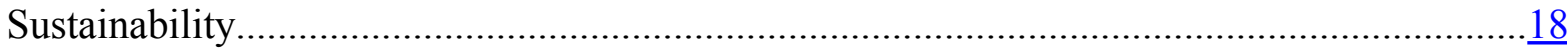

A. Lowering Inflationary Pressures and Improving Competitiveness ………………...18

B. Lessons from the Financial Crisis ..................................................................

C. Restoring Fiscal Sustainability .........................................................................

Figures

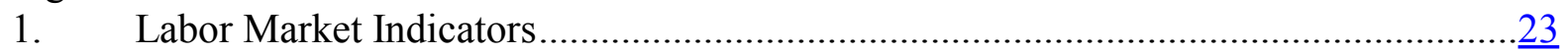

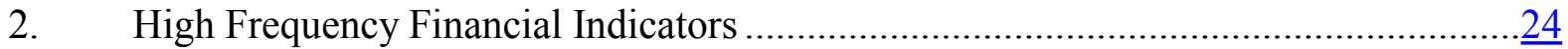

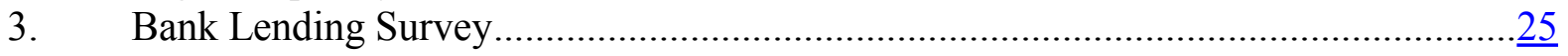

Tables

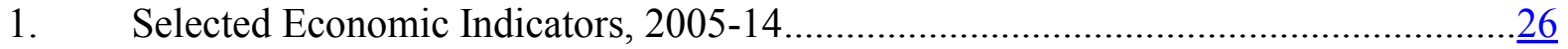

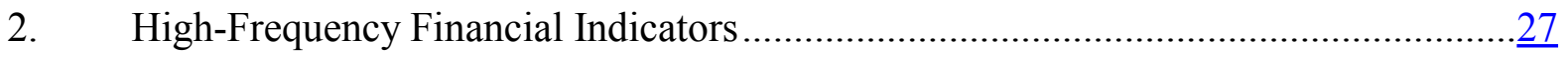

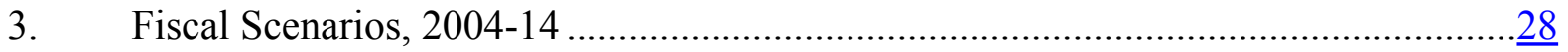

4. Public Sector Debt Sustainability Framework, 2003-13 …………………….........29

5. Financial Soundness Indicators of the Banking Sector, 2003-08 ……………….......

6. Financial Soundness Indicators of the Non-Banking Sectors, 2002-08 ........................ 


\section{Boxes}

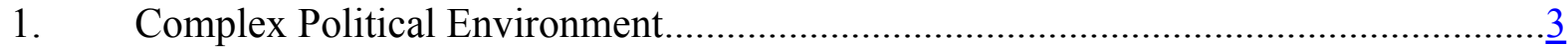

2. Belgium's Banking Sector .............................................................................

3. Belgium's Financial Crisis: Summary of Government Interventions ………................14

4. Fiscal Costs of the Response to the Financial Crisis ................................................16

\section{Annexes}

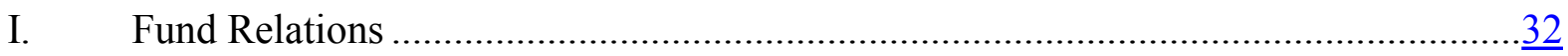

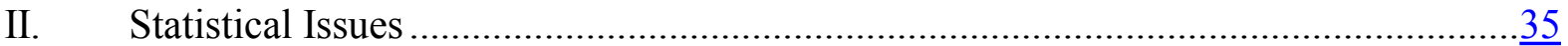




\section{Staff APPRaisal AND EXecutive SUMMARY ${ }^{1}$}

1. Belgium currently faces an extraordinary set of economic challenges. The global financial crisis has hit the country particularly hard in recent months, forcing government intervention in major financial institutions. The crisis has also sparked a deep recession in Belgium, in line with the rest of Europe. The boom in energy and commodity prices in early 2008 caused inflation to spike to well above the euro area average, creating risks of secondround inflationary effects and damaging competitiveness. In addition to continued fragility in the financial sector, the crisis has also highlighted fault lines and structural weaknesses that aggravated the impact of the exogenous shocks and which need to be tackled for the Belgian economy to recover resilience, return to growth, and prepare for long-term challenges. In particular, the long-run fiscal health of the country remains at risk due to high indebtedness and the future costs of an aging population; the existing fiscal federalism arrangements are creating unsustainable imbalances; and structural rigidities persist, dampening growth, impeding job creation, and eroding Belgium's competitive position in the world. Political uncertainty is currently high (Box 1), complicating prospects for decisive action to address the economic difficulties.

\section{Box 1. Complex Political Environment}

After parliamentary elections in June 2007, negotiations on a new federal government were prolonged, necessitating a caretaker administration until Yves Leterme was finally able to form a government in March 2008. The coalition proved to be fragile - the New Flemish Alliance Party withdrew in September after months of uncertainty over failure to reach agreement on measures to further devolve power to the regions, leaving Leterme with a reduced parliamentary majority. In December, allegations that the government tried to influence a court decision on the break-up of Fortis Group led to the resignation of Leterme and his government. Former Budget Minister Hermann Van Rompuy was named as the new Prime Minister, but will head the same delicate fractious coalition as his predecessor. Prospects for a more stable political environment are further limited by the approach of regional elections (scheduled for June 2009).

Despite the political environment, the authorities responded quickly and decisively to the financial sector crisis. However, the 2008 federal budget was delayed by the lack of a government and was less ambitious than originally envisaged. The 2009 budget was late and based on outdated macroeconomic assumptions, and legislative action on a fiscal stimulus package is incomplete. The new government will be facing serious challenges, including completing work on the budget and stimulus package, dealing with the legacy of the legal case regarding Fortis, supporting the social partners' wage agreement for 2009-10, as well as dealing with pending institutional issues. Clearly, adopting structural measures looking beyond the crisis will be difficult in this environment.

\footnotetext{
${ }^{1}$ A team comprising Mr. Franks (head), Mr. De Broeck, Mr. Jarmuzek and Ms. Yontcheva (all EUR) visited Brussels during December 3-16, 2008. Belgium is an Article VIII country and data provision is adequate for surveillance (see Informational Annex).
} 


\section{Belgium will suffer a significant recession in 2009 , and economic activity will} likely remain weak into 2010. Economic stimulus packages in many countries and looser monetary policy will help cushion the global downturn, but growth is still expected to fall to around -2 percent in 2009 , and it will remain below potential in 2010 , as the recovery in the world economy will be slowed by the aftermath of the financial crisis. Risks to the forecast are large and tilted to the downside, reflecting the uncertainties surrounding the international environment. The spike in inflation experienced in early 2008 has begun to reverse, but some second round effects are being observed, slowing the drop in inflation and harming competitiveness.

3. As the financial crisis exploded in Belgium, the authorities responded decisively. Action was quick, comprehensive, and coordinated in Fortis, Dexia and KBC banks and in insurance company Ethias in September-October. However, the authorities have now to deal with legal complications in case of the Fortis operation, and risks in the financial system remain elevated. A broader intervention framework should now be established to guide future actions, including a legal framework that provides pre-established rules for future interventions and allows significant further financial resources to be mobilized if needed (as has been done in other countries). Specific contingency plans should be prepared for further action (if needed) in each of the major banks, in smaller banks, and in the insurance industry. Further intervention should involve EU-wide coordination. The rapid expansion of some Belgian banks in emerging market economies has been beneficial for both Belgium and host countries, but also has translated into increased risks. In the current context of deleveraging, a strong focus on risk management by the banks and effective cross-border cooperation between supervisors are paramount. In addition, the Belgian authorities should continue to press for an expansion of pan-European banking supervision mechanisms while simultaneously strengthening existing venues of cooperation. At home, immediate steps should be taken to further strengthen information sharing and coordination between the Banking, Finance and Insurance Commission (BFIC) and the Belgian National Bank (NBB), and consideration should eventually be given to unifying macrofinancial risk analysis with banking and insurance supervision under a single structure.

\section{The fundamental challenge for the public finances is to use fiscal policy to} address short-term need for stimulus without derailing medium- and long-term fiscal consolidation objectives. Fiscal policy in 2009 should allow for full operation of the automatic stabilizers, plus a moderate discretionary stimulus (around 1 percent of GDP). The stimulus should be more timely and targeted than proposals advanced in late 2008 by the Leterme government, and measures should be tied to structural fiscal improvements aimed at ensuring longer-term sustainability. If the economic situation were to deteriorate significantly further, a larger stimulus might have to be considered, but only in coordination with the EU.

5. Once the current crisis is past, the fiscal stance will have to be significantly tightened to achieve long-run sustainability. The financial crisis has boosted the gross 
debt-to-GDP ratio by some 6 percentage points, and the deficits in 2008 and 2009 will further increase public indebtedness, complicating long-term fiscal sustainability. As an anchor to fiscal policy, the government - in collaboration with regions and communities - should firmly commit now to a structural adjustment of at least 0.7 percent of GDP per year once the crisis has past, to return as soon as possible to fiscal balance, and eventually to a surplus to ensure fiscal sustainability.

6. The consolidation strategy should be supported by fiscal institutional reforms. These could include: multiyear budgeting with binding spending ceilings, strengthening the role of the High Finance Council, and undertaking comprehensive expenditure and revenue reviews. Moreover, it will be crucial to tackle the imbalances inherent in the current fiscal federalism arrangements, by shifting more of the burden of fiscal consolidation and preparation for population aging from federal/social security to community/regional entities, and by addressing the horizontal imbalances between communities/regions.

7. Structural weaknesses need to be addressed. An emerging competitiveness gap is evidenced by declining Belgian shares in European markets, an appreciating real effective exchange rate, and a deteriorating external current account balance. The spike in inflation uncovered fault lines in the oil price-setting mechanisms and sparked concerns over competition in retail. Actions should be taken to raise productivity and market efficiency to boost competitiveness and improve the living standards and purchasing power of workers and their families.

- In the labor market, consideration should be given to modifying indexation mechanisms within the current centralized bargaining framework so as to achieve greater real wage flexibility, together with reforms to improve activation policies and increase training opportunities focused on improving labor productivity.

- In product and services markets, easing of restrictions on new retail establishments and deregulating opening hours and sales periods would promote a competitive environment leading to lower prices to consumers.

- $\quad$ More transparency in energy supply should be used to guard against abuse of market power and tighter regulation in energy distribution should help guarantee a fair evolution of distribution prices.

- $\quad$ The Competition Council should be reinforced to make it both a vocal public advocate for competition and a watchdog against rent-seeking behavior. 


\section{Current Crisis ANd OUtlook}

\section{A. Macroeconomic Outlook}

8. The current downturn is bringing to an end several years of strong economic growth. GDP growth averaged over 2.6 percent from 2004-07 in an expansion that helped create jobs, reduce unemployment, and maintain fiscal balance (Table 1). The upswing was sustained by robust domestic investment and strong economic activity in partner countries. Growth weakened significantly in the third quarter of 2008, and leading indicators suggest it turned sharply negative in the fourth quarter. Business and consumer confidence indicators are slumping, industrial production has begun to fall, and credit conditions have tightened.

\section{Belgium will experience a deep} recession in 2009. Staff anticipate growth of -2 percent in 2009. All components of domestic demand will be affected. Consumption will drop as confidence effects and rising unemployment cause consumers to retrench despite the sustaining effects of wage indexation on household incomes. Business investment will shrink as the reduction in demand lowers profit margins and reduces the capacity for self financing, in an environment with higher credit costs and more difficult external financing. Financing restrictions will also produce a sharp drop in residential investment. Government consumption and investment growth will remain positive, reflecting the automatic stabilizers and a modest fiscal stimulus.
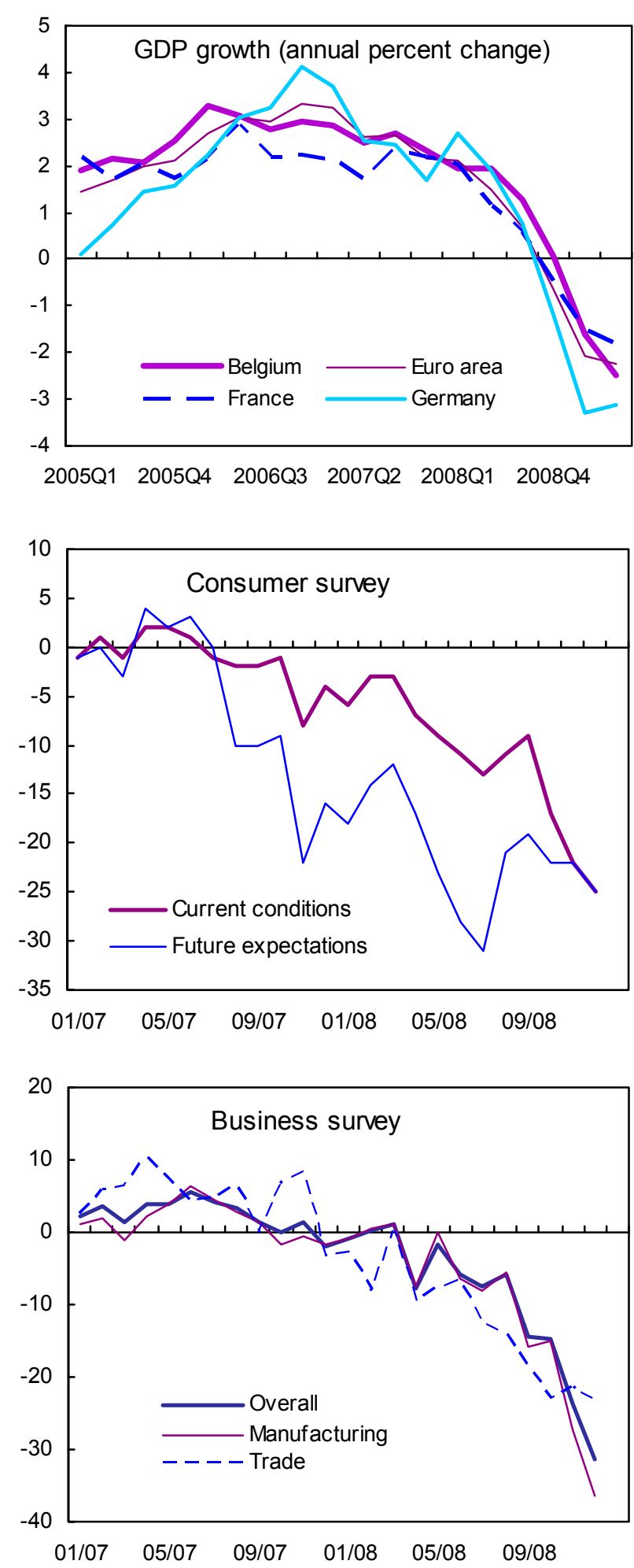
10. The global slowdown will also produce a decline

in external demand. Belgium's open economy is highly exposed to the downturn expected in partner countries. ${ }^{2}$ Slumping exports will accentuate the negative foreign contribution to growth, compounding an already existing trend of weak export performance. Belgian exporters have been losing market share since 1995, as they export mainly to slower growing economies, do not specialize enough in differentiated high-value added products, and suffer from eroding competitiveness in unit labor cost terms.

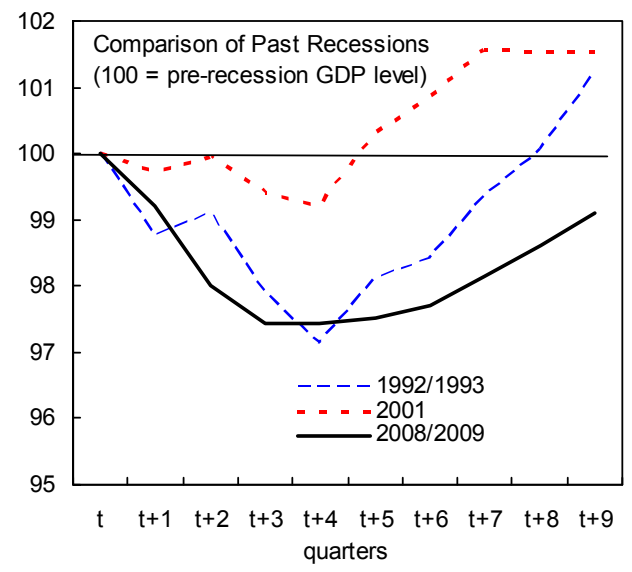

11. Risks to the forecast are large and tilted to the downside. Negative risks include: an additional decline in domestic demand if households increase their precautionary savings or due to credit constraints from another round of financial turmoil; a further worsening of the external sector as partner country demand slips by more than currently expected or if negative competitiveness effects are greater. On the positive side, EU-wide stimulus packages and aggressive actions to defuse further rounds of financial crisis may mitigate the downturn. Depreciation of the euro and falling ECB interest rate may also help sustain output by more than anticipated.

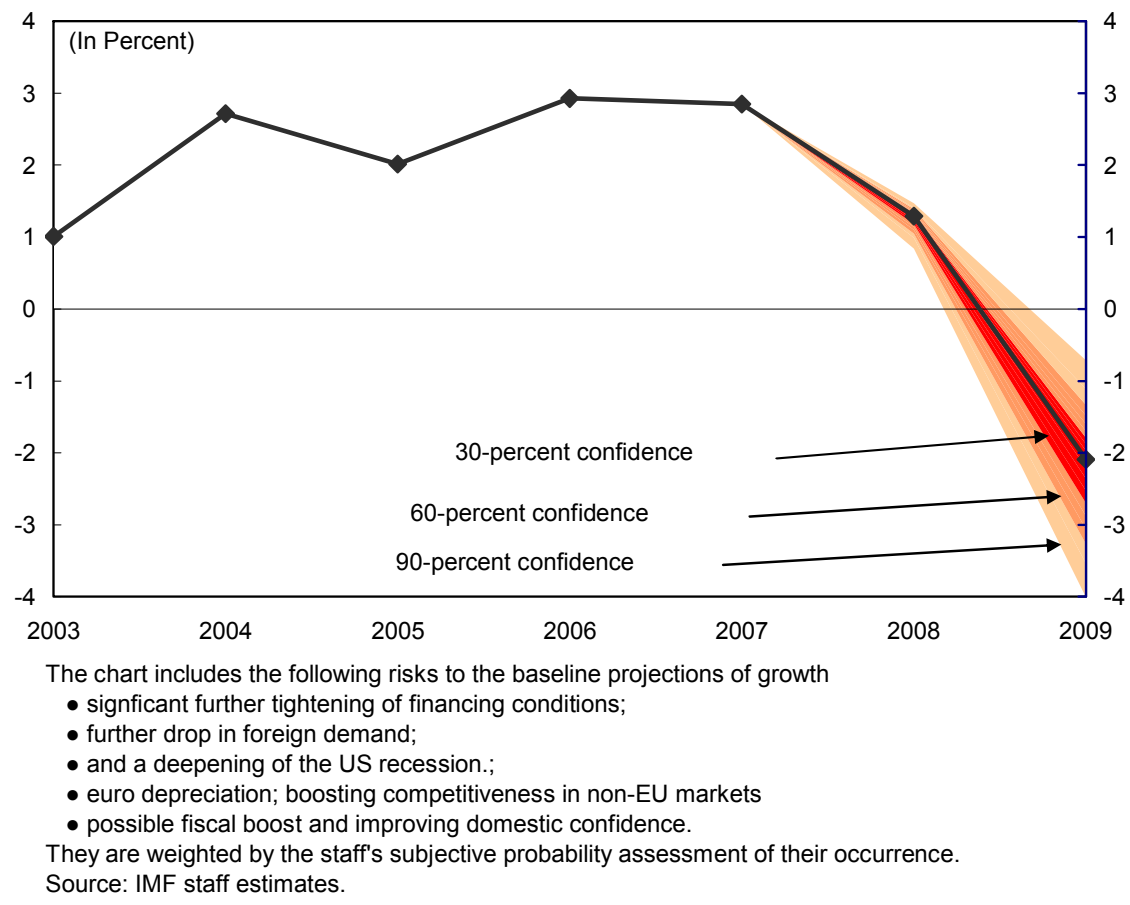

\footnotetext{
${ }^{2}$ Growth in 2009 is expected to be -2.5 percent in Germany and -1.9 percent in France.
} 


\section{B. Inflationary Effects of Commodity Price Shocks}

12. Increases in world energy and commodities prices produced a sharp inflationary spike. Fuelled by increases in world energy and commodity prices, Belgian headline inflation peaked in July, 2008, at 5.9 percent, year-on-year, almost 2 percentage points above the euro area average. While headline inflation is now falling sharply, it remains above that of euro area partners. As of December, Belgian HICP inflation stood at 2.7 percent, year-on-year, versus 1.6 percent in the euro area. For 2009, staff forecast Belgian inflation to remain above the euro area.

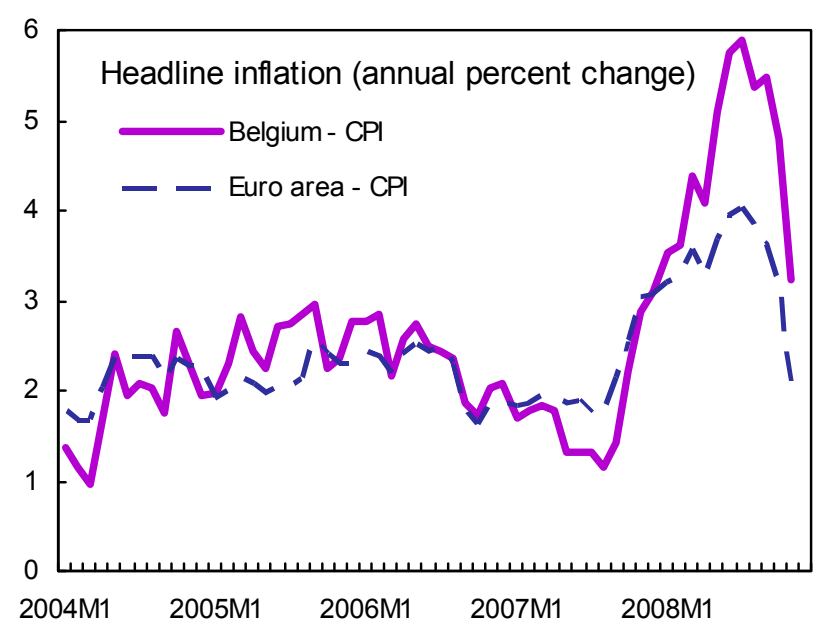

13. Second round inflationary effects are appearing. While energy and commodity prices have recently fallen, bringing domestic food and fuel inflation down sharply, other inflation components, notably those related to services, have not dropped. With public sector wages and about twothirds of private sector wages indexed with a delay to a core inflation measure, some pass-through of increased inflation is inevitable and wages will continue to rise in 2009, even as inflation drops. Under the recently concluded wage framework agreed by social partners for 2009-10 there will be a small additional wage increase beyond indexation. Trade union leaders acknowledged the risks to

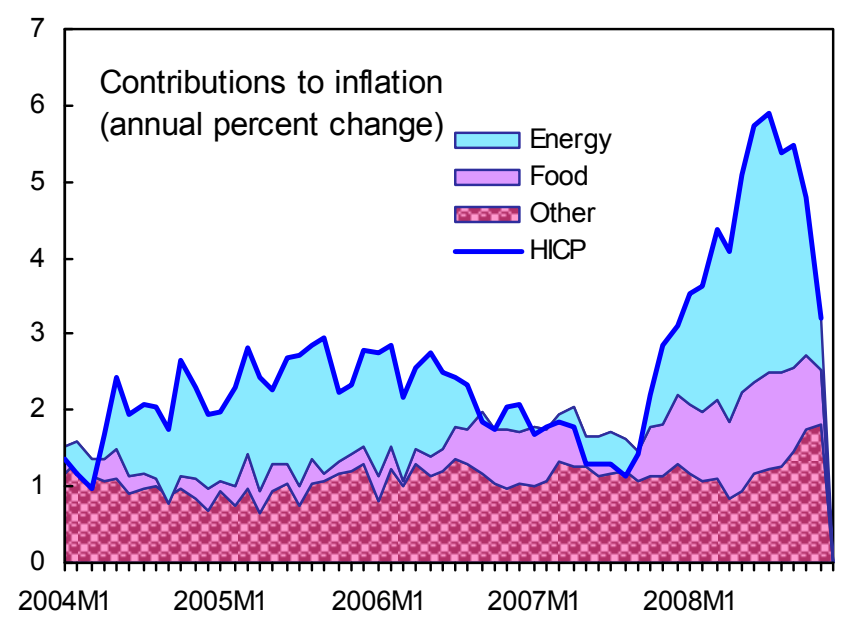
competitiveness but argued that recent price increases had raised social tensions. Hence, social partners proposed a reduction of the labor tax wedge as a solution to labor negotiations. The mission cautioned against broader wage increases and recommended that modifications could be made to indexation parameters (see paragraph 32).

14. The inflation differential between Belgium and the euro area raises concerns about possible imperfections in goods and products markets as well as in some pricessetting mechanisms. Part of the inflation differential is explained by compositional and 
measurement issues, ${ }^{3}$ but most of it is accounted for by differences in processed food prices, services prices, and gas and electricity prices (see figure below). This suggests the presence of downward price rigidities in the retail food industry, in services, as well as in the transmission and distribution of gas and electricity. The mission advised to seek ways to promote more competition in these areas.

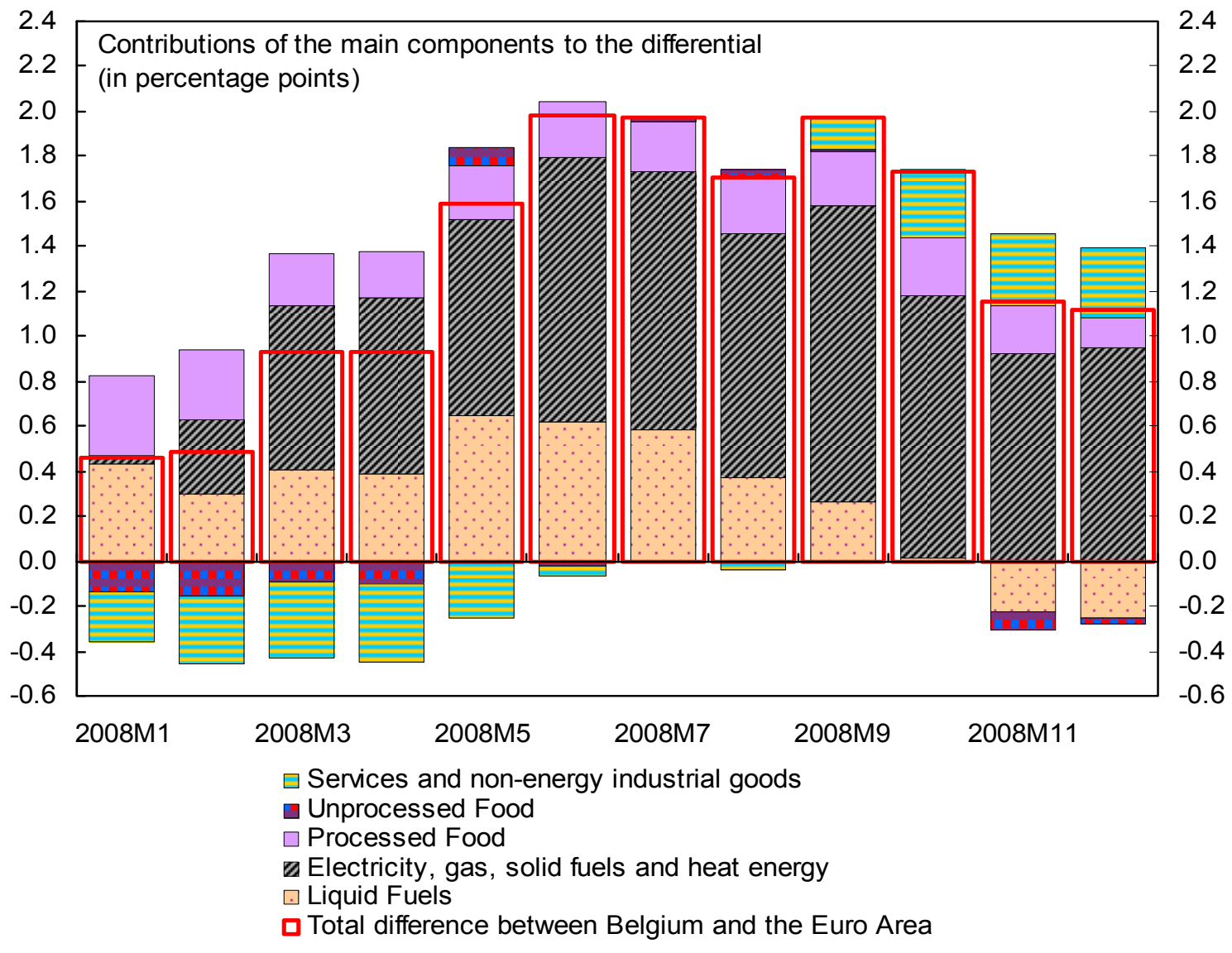

Source: HICP Database

\section{Competitiveness and the Real Effective Exchange Rate (REER)}

\section{Export performance in Belgium remained robust in the first half of 2008, but} competitiveness is deteriorating. Over the past year, imports grew more quickly, pushing the trade balance into deficit. The regional decomposition of exports show continued growth in intra-EU trade, while exports to the rest of the world have stagnated. For 2008 as a whole,

\footnotetext{
${ }^{3}$ (i) the CPI basket is more heavily weighted than the EU average with petroleum products and certain food product that had sharper prices increases and (ii) changes in CPI measurements for electricity and gas in early 2007 caused for quicker pass-through of energy prices in CPI
} 
preliminary estimates show a trade deficit for the first time in recent years, with a corresponding current account deficit. This compares to an average current account surplus of $3 \frac{1}{2}$ percent of GDP in the period 2002-06. Over the medium term, staff's baseline forecast is for current account deficits on the order of 2 percent of GDP, not a level likely to generate instability, but reflecting a deterioration of export competitiveness compared to recent years.

16. Analysis of the Real Effective Exchange Rate shows a worsening. Estimates using CGER methodologies show Belgium with an overvaluation on average of 5.6 percent (compared to 1 percent one year ago). The appreciation of the euro over the period accounts for part of the difference (and may be reversed Belgium: CGER Competitiveness Assessment (In percent)

Macro balances approach: 8.7

External sustainability approach: $\quad 1.5$ Equilibrium RER approach: $\quad 6.5$ Simple Average: with the recent decline in the exchange rate). However, there has also been an appreciation compared to key euro area partner countries, such as France, Germany, and the Netherlands since 2007. Developments in unit labor cost (ULC)-based real effective exchange rates point to a sharper decline in competitiveness, with a cumulative trade-weighted deterioration of 27 percent since 2000 (compared to a gain of 7 percent in Germany). Despite slow wage growth, labor costs remain higher than the average of the three major trading partners. Moreover, the wage indexation mechanism in Belgium is generating higher wage increases in 2008-9, exacerbating the gap in unit labor costs.
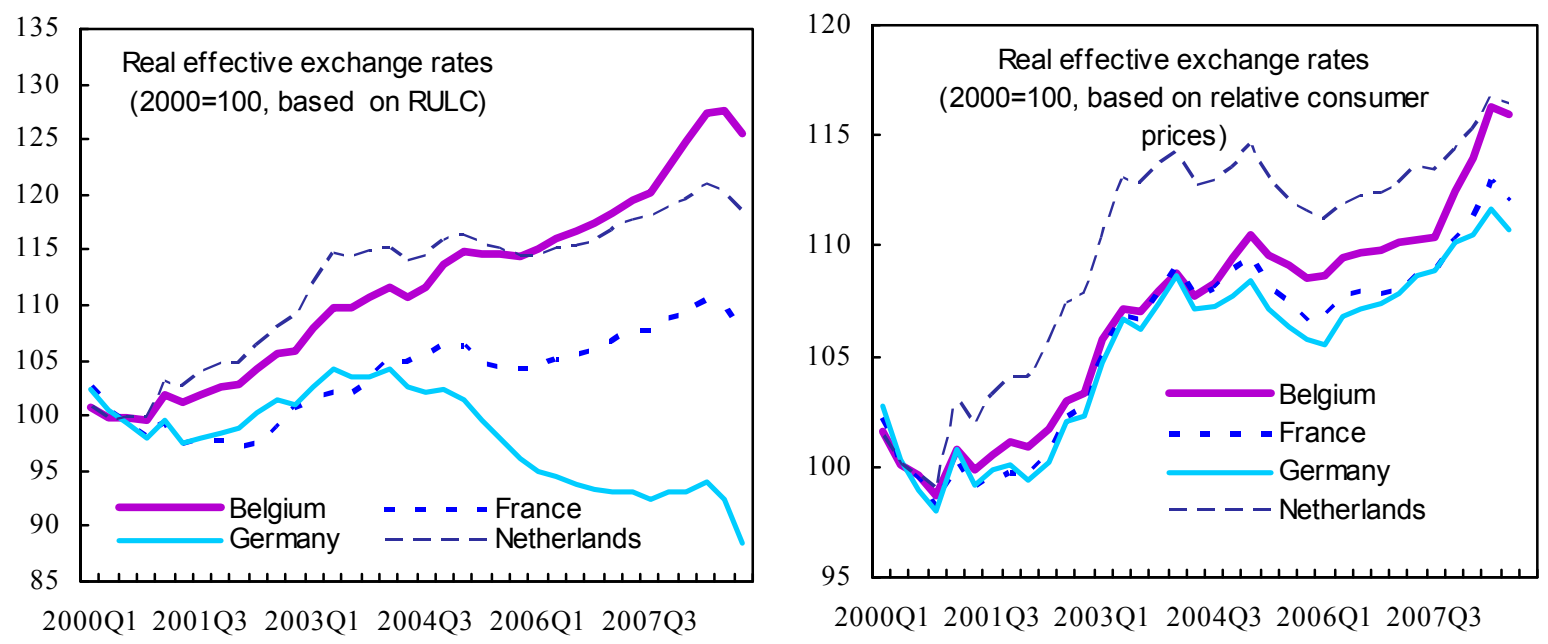

\section{The Financial Crisis and Macrofinancial Linkages}

\section{Belgium's financial sector weathered the early rounds of financial turmoil in} 2007, but succumbed in September-October 2008. The system's strong capitalization and moderate exposure to subprime risk appeared to confer relative resilience as the 2007 
liquidity shock broke (see Box 2 for a presentation of the banking sector). However, when some banks started to consolidate off-balance sheet exposure, they generated uneasiness about their earnings. Already by January 2008, volatility in equity prices indicated market concerns about asset valuations and their implications for banks' earnings and capital.

\section{Box 2. Belgium's Banking Sector}

The Belgian financial sector is large, internationally integrated and dominated by conglomerates. It comprises four large firms offering banking and insurance activities, the Euronext Brussels stock market, and a variety of other private entities. The banking sector is highly concentrated and offers both banking and insurance services. Past mergers and acquisitions have produced "bancassurance" groups which offer a wide range of financial services, providing clients with one-stop financial centers. The four main banks hold 80 percent of all banking assets, a not uncommon concentration in small countries, albeit much above the European average (about 45 percent). Over the past decades, in the context of ongoing integration of European financial markets, reforms have liberalized international flows, privatized banks, and deregulated financial and insurance activities.

\begin{tabular}{lcccc}
\hline & $\begin{array}{c}\text { Market Share } \\
\text { Banking }\end{array}$ & $\begin{array}{c}\text { Market Share } \\
\text { Insurance }\end{array}$ & $\begin{array}{c}\text { Share of Total } \\
\text { Profit: Banking }\end{array}$ & $\begin{array}{c}\text { Share of Total } \\
\text { Profit: Insurance }\end{array}$ \\
\hline Fortis & 31.9 & 17.8 & 85.7 & 14.3 \\
KBC & 21.4 & 13.4 & 91.2 & 8.8 \\
Dexia & 14.7 & 6.4 & 93.1 & 6.9 \\
ING & 14 & 6.7 & 93.3 & 6.7 \\
Total & 82 & 44.3 & & \\
\hline
\end{tabular}

\section{Worsening world liquidity conditions in the wake of the Lehman collapse,} together with specific concerns about Fortis and Dexia banks, triggered the crisis in Belgium in September 2008. Already in early 2008, Dexia's CDS spread spiked due to a loss of confidence by investors in its U.S. monoline and the value of securitized mortgages in the United States, compounded later by concerns about the effects of the collapse of AIG (Table 2; Figure 2). In the case of Fortis-Belgium's largest bank-concerns focused on the costly and ill-timed acquisition of the Dutch operations of ABN-Amro in 2007. The purchase depleted Fortis's capital while the credit turmoil made it difficult to obtain needed liquidity. In addition, Fortis's contradictory statements about its involvement in the subprime market deeply affected market sentiment and investors and depositors' confidence dropped. As world financial conditions turned increasingly desperate, the authorities were forced to intervene in Fortis on September 28 and two days later in Dexia. The third large Belgian-owned bank, $\mathrm{KBC}$, had stronger capital and liquidity positions but faced increasing pressures in October as 
the crisis spread to Emerging European markets where it has a large presence, necessitating a government recapitalization. ${ }^{4}$

\section{The financial sector crisis will exacerbate the GDP downturn directly through the reduction in the sector's value added ${ }^{5}$ but most importantly indirectly through} macro-financial linkages. In the current environment, banks facing liquidity issues will not be able to lend enough to consumers and firms to help them stabilize their spending and maintain economic activity. Lending margins have increased for all borrowers regardless of the risk profile ${ }^{6}$ and banks have tightened lending criteria (Figures 2 and 3). This suggests the ability of banks to act as efficient intermediaries has been compromised as they fail to mobilize savings and allocate them effectively and therefore spread risks across the economy. In addition, financing through commercial papers and stock issuance has also become much more expensive in the last few months. ${ }^{7}$ Tightening credit conditions for both households and firms will contribute to the fall in investment and consumption this year. According to NBB estimates, a shock of 100 b.p. on the credit spread leads to a slowdown in business investment of 0.4 percent per annum while also reducing household investment in housing by 0.1 percent.

20. Finally, the stock market adjustment will trigger wealth effects. The Belgian stock exchange has lost nearly 45 percent of its value over the past year, depressing household assets by 15 percent. Wealth effects of such an adjustment are expected to reduce consumption growth by 0.5 percent per annum during 2 to 3 years. This is reflected in staff's forecast of an increased savings ratio from 12 percent in 2007 to $14 \frac{1}{2}$ percent by 2009, depressing private consumption and domestic demand.

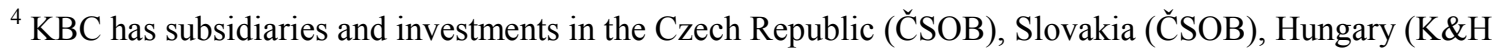
Bank), Poland (Kredyt Bank) and Slovenia (Nova Ljubljanska Banka). With effect from July 2008, KBC Bank acquired another small Slovakian Bank, Istrobanka. In practically all of these countries, KBC Bank is a top-three player by market share.

${ }^{5}$ The growth of financial intermediation value-added in real terms averaged 4 percent p.a. in past ten yearsperformance to be compared with an average GDP growth of 2.3 percent.

${ }^{6}$ For enterprises, margins have increased up to 63 basis points (b.p.). For mortgages, margins have increased up to 100 b.p. from June to October 2008.

7 The cost of financing through stock issuance has increased by 25 percent between June and September 2008 . The rate on BBB quoted bonds with a 5-to-7 year maturity increased by 150 b.p. from June to September.
} 


\section{Responding TO THE CRISIS}

\section{A. Rescuing the Banking Sector}

The authorities responded decisively once the financial crisis broke, intervening in the three largest banks and an insurance company. However, risks remain elevated, further bank losses and additional intervention cannot be ruled out. While the initial intervention was done on an ad-hoc basis, staff recommended moving to a more systematic approach.

21. Once the crisis broke, the Belgian authorities intervened decisively together with partner countries. During September-October 2008, the government was forced to step in to all three of the main Belgian-owned bancassurance groups, along with a medium-sized insurance company (Ethias) (Box 3). In the case of Fortis, initially there was a joint intervention with the Netherlands and Luxembourg, with a partial nationalization and capital injections and a management change. The Netherlands subsequently fully nationalized the Dutch assets of Fortis (including the ABN-Amro assets), and Belgium nationalized the remainder of Fortis, agreeing to sell Fortis's Belgian banking operations to BNP-Paribas while segregating toxic assets in an SIV and continuing to hold international insurance operations and some overseas operations. Dexia, a bank originally publicly owned and specialized in financing local and regional governments, had more stable deposit and investor bases, and the Belgian, French and Luxembourg governments jointly injected capital into the bank while providing funding guarantees to keep it afloat. The Belgian authorities also strengthened KBC's capital but without changing the current management. Intervention in the Ethias insurance group was necessitated by a severe weakening in the firm's assets due to the crisis and a poor investment strategy.

22. Risks to the Belgian financial system remain elevated. The government's timely action - along with those of the $\mathrm{ECB}^{8}$ and other governments- has brought some respite, but the situation is fragile. While there is some improvement in the liquidity situation, mistrust between market participants remains high. The market for unsecured financing reopened but repurchasing transactions are available only on overnight basis, with larger haircuts and with prime collateral. The court decision to suspend the sale of Fortis Bank Belgium to BNPParibas has heightened uncertainties and may ultimately require additional government financing unless a resolution can be reached quickly. A sharp drop in KBC's share price following a downgrade of some structured products in its portfolio prompted an additional capital injection by the Flemish government in January 2009. Additional intervention in Dexia cannot be ruled out, as liquidity remains tight. Finally, in staff's view, there are risks

\footnotetext{
${ }^{8}$ The European Central Bank (ECB) extended the list of eligible collateral and provided unlimited access to US\$ financing.
} 
that additional problems in other advanced economies or from emerging markets could spill over into Belgian banks or into insurance and investment companies.

\section{Box 3. Belgium's Financial Crisis: Summary of Government Interventions}

The authorities have provided direct support to Belgium's financial sector in two ways:

(i) Direct financial support to three major financial institutions-Fortis, Dexia and $\mathrm{KBC}$ - and to insurance company Ethias

- $\quad$ Fortis. The federal government invested $€ 9.4$ billion to acquire virtually all the equity in Fortis Bank, and [sold] a 75 percent stake to BNP Paribas in exchange for BNP Paribas shares.

- Dexia. The federal government and Belgium's three regions together invested $€ 2$ billion in Dexia, in exchange for 11.5 percent of Dexia's equity. In addition, the Belgian and French government guarantee up to $€ 12$ billion of toxic assets held in portfolio by Dexia.

- $\quad$ KBC. The federal government acquired $€ 3.5$ billion non-voting and non-transferable securities that qualify as core capital. The Flemish government has announced an additional $€ 2.0$ billion capital injection using similar securities.

- $\quad$ Ethias. The federal government, and the Flemish and Walloon regions each are contributing $€ 0.5$ billion to a capital injection in Ethias, a mutual insurance company.

(ii) Financial sector guarantees, including an increase in the deposit guarantee ceiling per depositor from $€ 20,000$ to $€ 100,000$; an extension on demand of the institution of the guarantee's coverage to insurance instruments akin to deposits; and the introduction of a temporary guarantee for interbank loans and short-term debt instruments issued by financial institutions. For the time being, only Dexia has asked and received a funding guarantee, which was granted jointly by the Belgian, French, and Luxembourgian governments and can engage the Belgian government up to an amount of $€ 90$ billion.

No additional interventions have been announced, but further capital injections or the granting of additional guarantees cannot be excluded. ${ }^{1}$

${ }^{1}$ In Dexia's case, a call of the guarantee on toxic assets will be equivalent to a capital injection as the Belgian and French governments will be entitled to receive Dexia shares in compensation.

\section{To handle any further difficulties, the mission recommended that the authorities} move from an ad hoc approach to a more systematic intervention strategy. This would involve putting in place pre-established rules for future interventions, allowing significant further financial resources to be mobilized if needed, and including a strategy for dealing with toxic assets, as has been done in other countries. Such a mechanism would help reassure markets that the financial system will remain secure while standardizing the criteria for 
intervention. Notably, legislation to transparently specify the overall room for and conditions of additional capital injections and funding guarantees could set clear parameters for future interventions, while boosting confidence in the government's backing of the system. The Government, BFIC, and NBB should also develop tailored contingency plans for further action (if needed) in each of the major banks, in smaller banks, and in the insurance industry, detailing the steps to be taken in the event of another round of crisis. While many officials agreed with the staff's recommendation to put in place a framework for intervention, others felt that the existing ad hoc arrangements are adequate to deal with any future difficulties.

\section{B. Fiscal Policy}

Fiscal policy in Belgium must balance two competing demands. On the one hand, there is a need for government support for the financial sector and for fiscal stimulus to cushion the economic downturn. On the other hand, a high government spending-to-GDP ratio, continued high indebtedness, and an aging population require adjustments to make the public finances sustainable in the longer-term. Fiscal policy has responded to the short-term challenges, but a medium-term consolidation strategy that can address aging-related and sustainability issues has not yet been announced.

24. The $\mathbf{2 0 0 8}$ general government budget outturn fell short of target. After the budget had slipped into deficit in 2007 , the new federal government that took office in the spring of 2008 intended to return to budget balance and a medium-term fiscal consolidation strategy aimed at gradually building surpluses (Table 3). However, the 2008 federal budget was only approved in May, limiting the impact of adjustment measures, and communities/regions rejected the federal government's request to make an additional contribution to the adjustment effort. A revenue shortfall induced by the weakening economic growth in the second half of the year pushed the balanced budget objective even further out of reach. As a result, the general government deficit is estimated to have widened from $1 / 4$ percent of GDP in 2007 to about 1 percent of GDP in 2008. Public debt was boosted by nearly 4 percentage points of GDP by the cost of the support to the financial sector (Box 4). 


\section{Box 4. Belgium: Fiscal Costs of the Response to the Financial Crisis}

With the exception of the $€ 500$ million capital injections by the Flemish region in both Dexia and Ethias, which are financed by drawing down assets, direct financial support from the federal government and regions is funded through borrowing. This will translate into an increase in general government debt of $€ 19.4$ billion (somewhat more than 5 percent of 2009 GDP). With capital injections considered to be financing transactions, they would have no impact on the general government balance other than the increase in interest payments (negative) and possible dividends and coupon payments (positive):

- $\quad$ At current interest rates for 10-year government bonds, the corresponding interest payments would be around $€ 850$ million annually (around 1/4 percent of 2009 GDP).

- $\quad$ Possible dividends from the federal government and the regions' participation in Dexia, Ethias and Fortis Bank will be part of general government revenue. The KBC securities entitle the federal government annually to the higher of either $€ 2.51$ per security (yielding 8.5 percent) or 110 percent of the dividend paid in 2009 and 115 percent of the dividend in the following years. However, the federal government will not receive any payment in years when KBC is not expected to distribute a dividend (notably, 2008).

The additional guarantees granted by the federal government create contingent liabilities but do not yet raise the debt or deficit. Financial institutions will have to pay a fee to benefit from the guarantees, with the draft 2009 budget estimating the additional revenue from fees at $€ 100$ million for the higher deposit guarantee and $€ 500$ million for the new bank funding guarantee.

\section{Staff and the authorities agreed that Belgium's ability to respond to the} downturn with large fiscal stimuli is limited by its high indebtedness and population aging. The public cost of the financial sector bailout has already boosted the debt-to-GDP ratio to nearly 88 percent of GDP. While no public financing constraints have yet materialized, the spread on Belgian debt has risen sharply (to above100 b.p.), and ratings agencies recently downgraded the sovereign outlook from positive to neutral. Moreover, fiscal surpluses will be required in the future due to the long-term challenges of population aging (discussed below). For these reasons, staff viewed a moderate discretionary

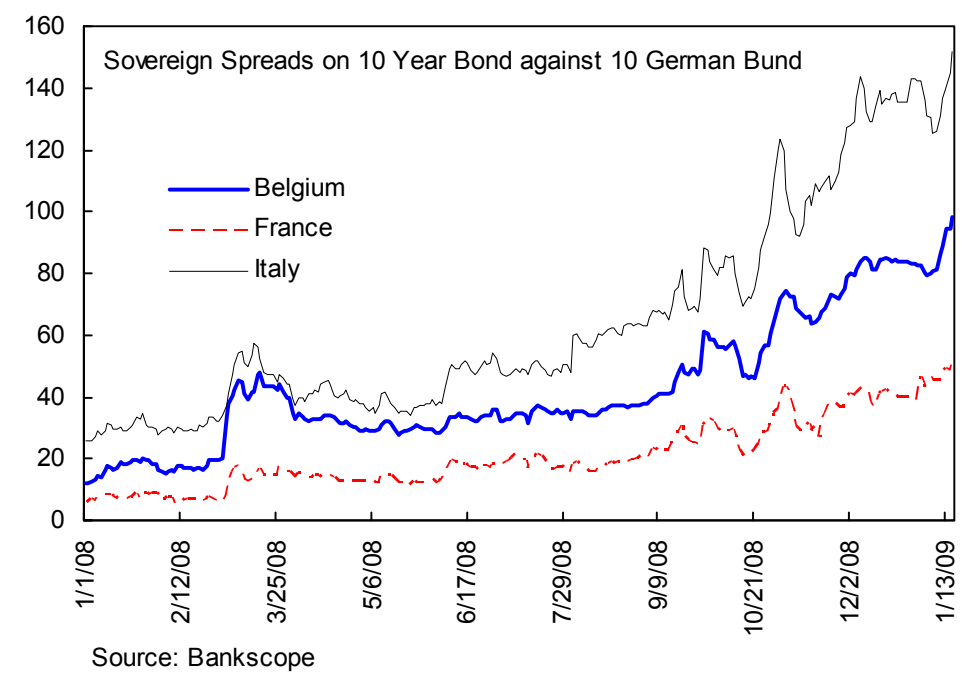


stimulus (around 1 percent of GDP) as appropriate, notwithstanding the severity of the downturn. The authorities largely shared staff's concerns, with political pressures remaining strong to keep the deficit in check. They pointed out that a debt policy based on transparent communication and aimed at prudently managing rollover and repricing risks would limit the repercussions of higher indebtedness on the availability and cost of financing.

26. The budget for 2009, together with a stimulus package announced in December, would provide a fiscal impulse of around 1 percent of GDP. The federal draft budget submitted in November still envisaged a balanced general government budget, but only due to the overly optimistic macroeconomic assumptions. ${ }^{9}$ The federal government in early December abandoned the balanced budget target: it revised the real GDP growth forecast for 2009 down to -0.2 percent and in tandem announced a new fiscal stimulus package. Approval of the budget was delayed until January by the collapse of the Leterme government, and measures from the new package have yet to be approved by parliament under new Prime Minister Van Rompuy.

\section{The proposed stimulus package (Plan de Relance) focuses on reducing social} contributions and boosting investment spending. At the federal level, the proposed measures include new and accelerated public investment, across-the-board reductions in social security contributions, a VAT reduction for selected construction activities, an increase in benefits for temporary unemployment, a limited subsidy for household electricity consumption, and steps to improve the liquidity position of the enterprise sector. The federal government also invited the regions to each formulate its own set of measures. The regional emphasis is on public investment in infrastructure and energy conservation, employment subsidies, and guarantee schemes to facilitate enterprise access to bank loans.

28. In staff's view, the composition of the proposed fiscal stimulus package could be improved. In particular, the mission recommended less ambitious public investment targets: there are limits to how much new projects can be initiated and existing ones can be brought forward in order to bring the stimulus to bear at the moment when it is most needed to cushion the downturn, the first half of 2009. The authorities disagreed on the grounds that relevant projects and timetables already have been identified. Staff argued to include sunset clauses or long-term countervailing savings for some expensive reductions in social contributions and increases in unemployment and other social benefits, a reversal of which was not envisaged in the Plan de Relance. Government officials conceded that these measures would be permanent, but considered this appropriate in view of their longer-lasting benefits. Staff also saw room to sharpen the focus of the proposed cuts in social security

\footnotetext{
${ }^{9}$ GDP Growth of 1.2 percent was envisaged, with only a marginal increase in unemployment.
} 
contributions and hikes in social benefits on increasing incomes of those most likely to spend it (e.g. the low-income and unemployed).

\section{Staff projects a headline general government deficit between $2 \frac{1}{2}-3$ percent of}

GDP in 2009. Letting automatic stabilizers operate freely would, using staff's growth projections, translate in a year-on-year widening of the headline general government deficit by slightly more than 2 percent of GDP. Staff also projects the Plan de Relance, together with some measures, including one-offs, previously announced in the draft 2009 budget, to boost the structural deficit by around $3 / 4$ percent of GDP (Table 3). Staff accepted that additional stimulus might have to be considered given the deteriorating economic situation, but cautioned that this would be appropriate only in coordination with the EU. With slow growth extending into 2010, the deficit would remain around 31/2 percent of GDP over the period 2010-2012 under current policies.

\section{BEYOND THE CRISIS-RESTORING GROWTH, ENHANCING RESILIENCE, AND RETURNING Fiscal SUSTAINABILITY}

The serious economic and financial crises have forced postponement of needed fiscal consolidation, and have also uncovered some fault lines in the structure of the economy. Staff recommended that the authorities not lose sight of these longer-term challenges, using the downturn to crystallize awareness and boost willingness to reform.

\section{A. Lowering Inflationary Pressures and Improving Competitiveness}

30. The sharp economic slowdown just after an inflation peak revealed weaknesses in price- and wage-setting mechanisms that inhibit rapid adjustment. Two separate dimensions need to be taken into account: on the one hand, the pass-through of oil and commodity shocks to domestic food and fuel prices ought to be strictly in line with best competition practices, and on the other hand, wage moderation to restrain second-round effects is needed.

\section{Staff recommended improved competition policies to enhance efficiency in good} and products markets:

- $\quad$ The mission recommended further reinforcing the Competition Council as a vocal public advocate for competition and a watchdog against rent-seeking behavior. The Council should accordingly be empowered and sufficiently staffed to analyze areas where policy changes could boost competition. In addition, cooperation between the Competition Council and sectoral regulators should be reinforced.

- In the retail sector, easing of restrictions on new retail establishments, opening hours, and sales periods would allow for lower consumer prices. Deregulating prices and 
liberalizing the market for over-the counter drugs would benefit the consumers while easing the administrative burden on the Ministry of Economic Affairs. ${ }^{10}$

- In energy supply and distribution, the mission welcomed the recently enhanced investigation power of the sectoral regulator (CREG) but also recommended additional actions to obtain more transparency for the end user.

Reforms along these lines could lower the consumer price level by as much as 1-2 percentage points over time, boosting purchasing power by hundreds of euros per household while narrowing the external competitiveness gap.

\section{Wage indexation has sustained domestic demand, but has also produced real} wage rigidity, which is perpetuating inflationary pressures and hurting competitiveness. The centralized wage bargaining arrangements have served Belgium well by internalizing macroeconomic considerations in wage setting, but combining these with economy-wide indexation is perpetuating difficulties from the inflation spike. Staff recommended that the government and the social partners give consideration to reforming the wage indexation parameters to permit full coverage for the poorest, most vulnerable workers, while allowing for less-than-complete indexation for the economy as a whole. Social partners were aware of the risks of real wage rigidity, but resisted breaking with full indexation, seeing the competitiveness and inflation problems as temporary ones that would soon reverse.

\section{B. Lessons from the Financial Crisis}

\section{While the ad hoc interventions in September and October were well-handled, significant risks remain and a broader intervention framework should now be established to guide future actions. Steps that should be taken include:}

\section{- $\quad$ Strengthen information sharing and coordination between the BFIC and the}

NBB. This could include creating joint databases for offsite inspections of banks, and joint onsite inspection teams between banking supervisors from the BFIC and macrofinancial risk experts from the NBB. The BFIC and the NBB would have to be fully committed to intense cooperation if the new structure is to be effective and efficient. Eventually, consideration could be given to unifying macrofinancial risk analysis with banking and insurance supervision under a single structure, ${ }^{11}$ while leaving supervision of financial markets in a separate institution. The authorities'

\footnotetext{
${ }^{10}$ Price deregulation has, however, to go hand-in-hand with market liberalization for the consumer to reap the benefit in terms of price reduction.

${ }^{11}$ Supervision under a single structure could foster a culture of mutual trust, open communication, and common objectives.
} 
reactions to these proposals were mixed, with the BFIC arguing that current arrangements were working well.

- $\quad$ Further improve on-site inspections. Supervisors will need resources to ensure that their capacity to identify risks keep pace with the increasing sophistication of financial instruments and the complexity of bancassurance conglomerates.

34. The rapidly expanding exposures of Belgian banks in EME created high profit opportunities but also increased credit risks, in particular those related to foreign currency lending. As macroeconomic conditions worsen in EME countries, loan quality may deteriorate. Any abrupt correction of the prevailing macroeconomic imbalance could - in the current climate of exacerbated risk aversion-lead to sizeable losses. To help promote an orderly unwinding of assets in Belgian banks while preserving stability in host countries, Belgian authorities should pursue cross-border cooperation. Steps that should be taken include:

- Continue to press for an expansion of pan-European banking supervision mechanisms. In the meantime, priority should be given to strengthening existing venues of cooperation, such as supervisory colleges and bilateral memoranda of understanding with supervisors in other countries where Belgian banks are active.

- The supervisors should ensure that banks (i) appropriately manage indirect credit risk stemming from foreign currency loans, and (ii) promote borrowers' awareness of risk - both domestically and abroad.

\section{Restoring Fiscal Sustainability}

35. While fiscal deficits are part of a proper crisis response, they should not derail a medium-term fiscal strategy aimed at preparing for population aging and ensuring long-run fiscal sustainability. Staff and the authorities recognized that the authorities' stated medium-term strategy, which was based on High Finance Council (HFC) recommendations and centered on a gradual build-up of fiscal surpluses, had proven much more challenging than expected. In fact, even budget balance - an objective that had garnered broad-based consensus in Belgium in the wake of euro adoption - had been an elusive goal in 2007-08. But staff also emphasized that the financial crisis had boosted the gross debt-to-

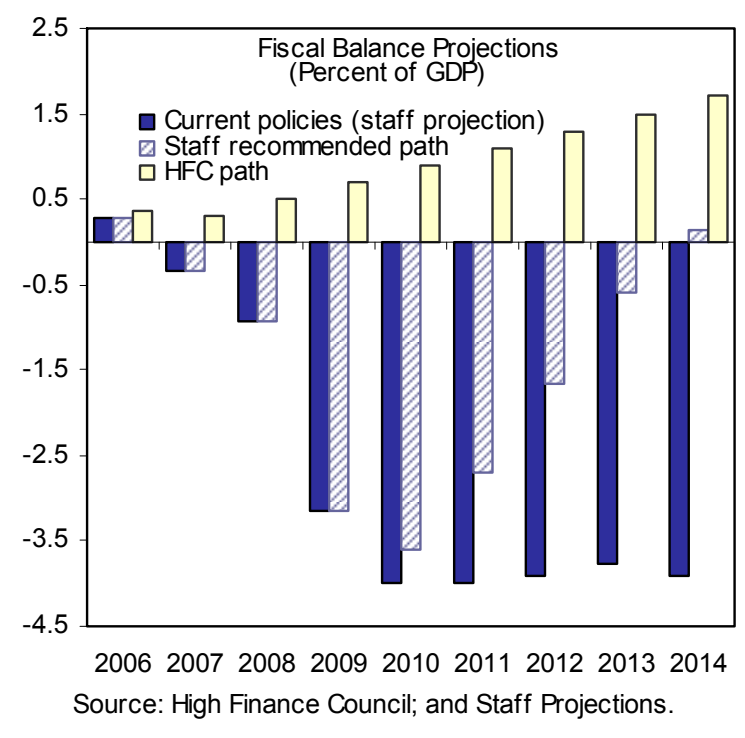


GDP ratio, and that deficits in 2009 and beyond would further increase public indebtedness, making it more difficult to ensure long-term fiscal sustainability. It was therefore imperative to establish a clear medium-term anchor to fiscal policy. A clearly articulated adjustment strategy aimed at returning the debt-to-GDP ratio onto a downward trajectory would help boost market sentiment and reduce the unfair distribution of ageing costs among generations. Staff recommended that the federal government - together with regions and communities should firmly commit already now to a structural adjustment of at least 0.7 percent of GDP per year once the crisis has past, to return as soon as possible to fiscal balance, and eventually to a surplus. The authorities indicated their intention to return to a medium-term consolidation strategy, without specifying underlying growth or policy assumptions.

\section{The medium-term fiscal adjustment strategy should be underpinned by budget}

process reforms. In staff's view these could include:

- A medium-term budgetary framework to guide the annual budget process. This would allow the government to articulate spending priorities and set out in detail plans for the main spending categories over a multi-year horizon.

- An enhanced role for the HFC. To the existing function of assessing compliance with Belgium's stability programs and recommending an appropriate medium-term fiscal stance, the HFC could take on the role of independent evaluator of submitted budgets and corresponding outcomes, producing regular reports. The HFC's mandate could be expanded to include expenditure policy issues and helping set parameters for the medium-term budgetary framework.

- More effective arrangements for coordinating fiscal policies among government levels. The current arrangements involving informal agreements between federal and community/regional governments should be converted into internal stability pacts that would be debated by legislatures as part of the regular budget cycle, be published, and have sanctions for non-compliance. Responsibilities for ensuring fiscal discipline at the local level need to be clarified, and the reporting standards for local authorities improved in conformity with ESA95 requirements.

- Comprehensive expenditure and revenue reviews. Such reviews can help identify areas where tax expenditures can be reduced, and spending streamlined and improved in efficiency. They also could help Belgium find ways to reduce the size of government, which — at nearly 50 percent of GDP — is above the average for advanced countries.

The authorities were receptive to these suggestions, indicating that the IMF could play a useful role in helping identify international best practice in budgeting. 


\section{Increasing strains in Belgium's fiscal federalism arrangements need to be}

tackled through further institutional reforms. Staff and the authorities agreed that vertical imbalances between the federal level and communities/regions were deepening as the federal government transfers an increasing share of its revenues to communities/regions, and also bears the brunt of the increase in health- and aging-related spending. Addressing these vertical imbalances is complicated by horizontal imbalances between communities/regions. Staff argued that the institutional reform dialogue recently initiated by communities and regions would offer an opportunity to reconsider the horizontal imbalances, with a view to providing a better match between spending authority and revenue-raising responsibilities and improving the transparency and incentive effects of intergovernmental solidarity mechanisms. 
Figure 1. Belgium: Labor Market Indicators
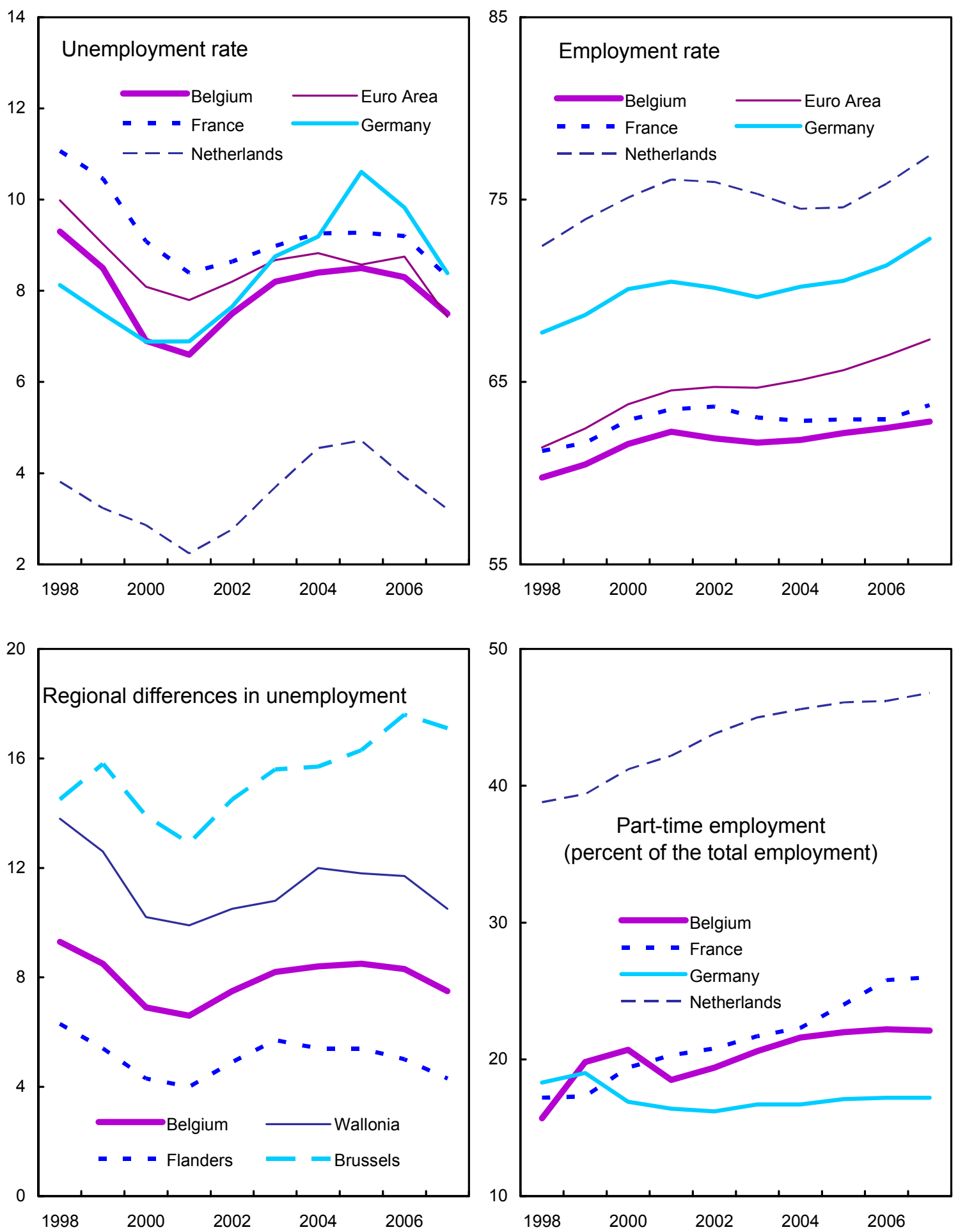

Sources: Global Insight; OECD: and IMF, WEO. 
Figure 2. Belgium: High Frequency Financial Indicators
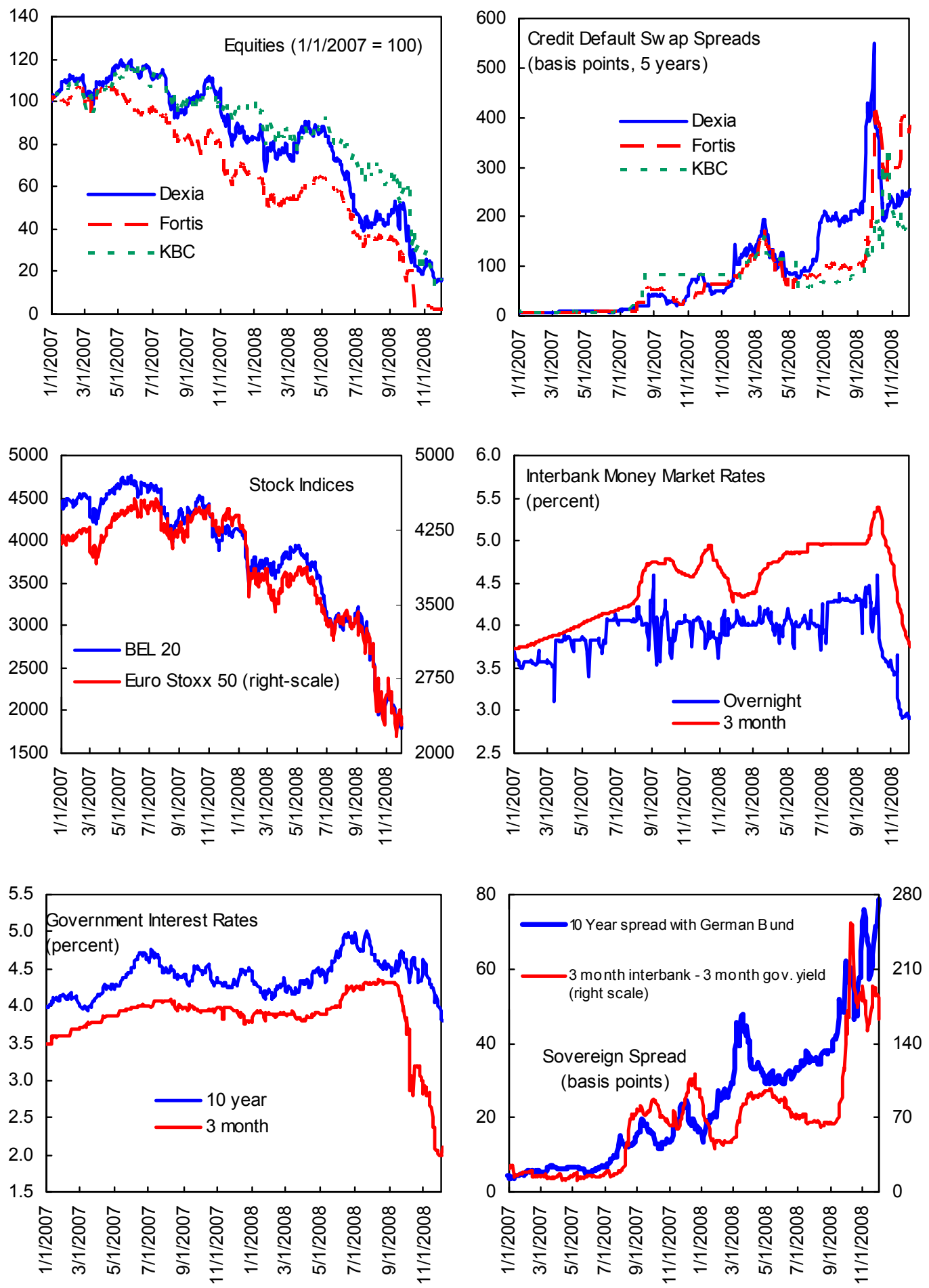

Sources: Thomson Financial/DataStream and Bloomberg. 
Figure 3. Belgium: Bank Lending Survey $1 /$
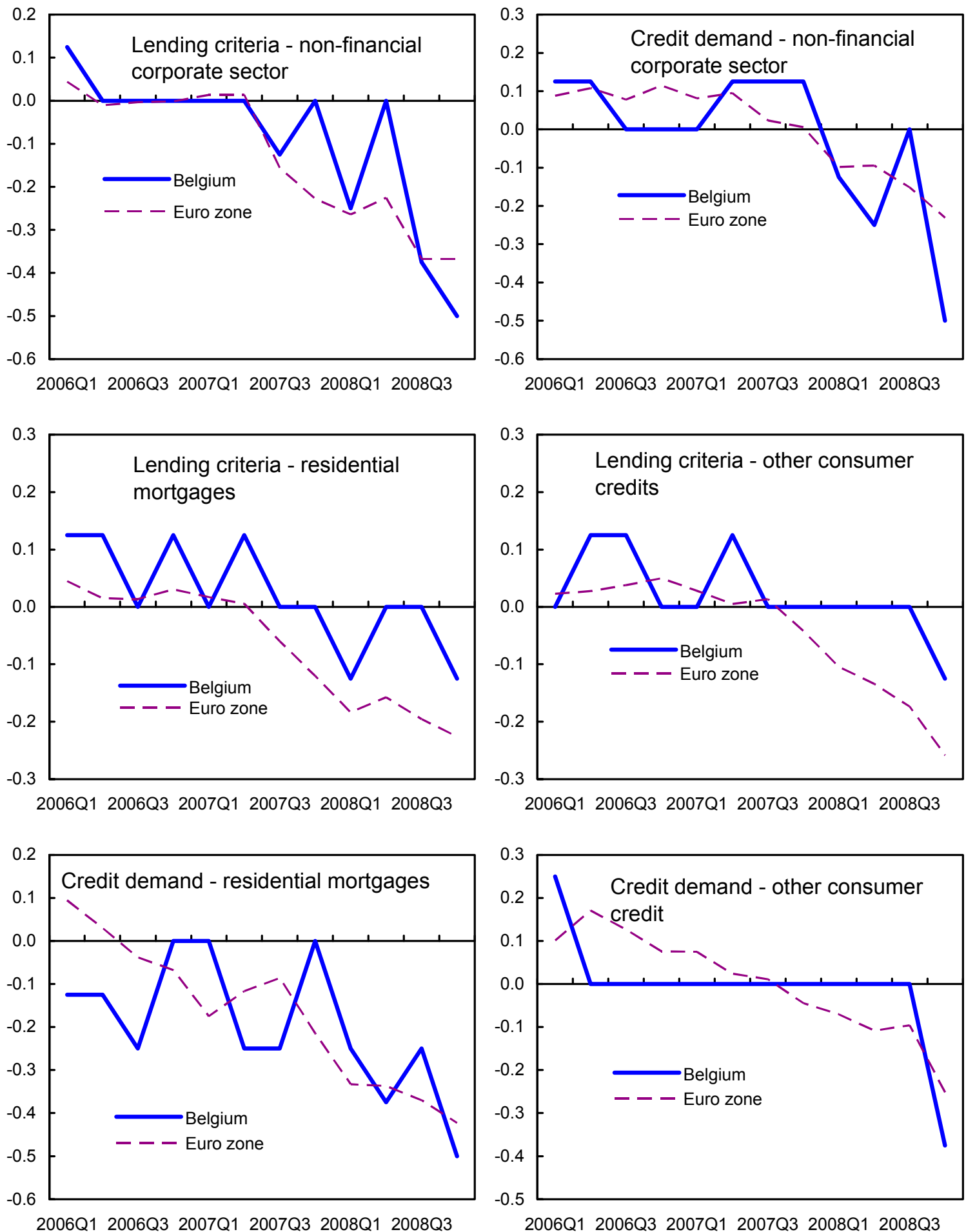

Source: National Bank of Belgium.

1/ Data above the zero line are looser conditions and below the zero line are tighter conditions. 
Table 1. Belgium: Selected Economic Indicators 2005-14

\begin{tabular}{|c|c|c|c|c|c|c|c|c|c|c|}
\hline & \multirow[b]{2}{*}{2005} & \multirow[b]{2}{*}{2006} & \multirow[b]{2}{*}{2007} & \multicolumn{7}{|c|}{ Projection } \\
\hline & & & & 2008 & 2009 & 2010 & 2011 & 2012 & 2013 & 2014 \\
\hline & \multicolumn{10}{|c|}{ (Percentage change from the previous period; unless otherwise indicated) } \\
\hline \multicolumn{11}{|l|}{ Real economy } \\
\hline Real GDP & 2.2 & 3.0 & 2.6 & 1.3 & -2.1 & 0.8 & 2.0 & 2.2 & 2.3 & 2.3 \\
\hline Private consumption & 1.5 & 2.1 & 2.0 & 0.9 & -0.7 & 0.8 & 2.4 & 2.4 & 2.2 & 2.2 \\
\hline Public consumption & 0.4 & 0.1 & 2.3 & 2.0 & 1.8 & 1.7 & 1.8 & 1.8 & 1.8 & 1.8 \\
\hline Gross fixed investment & 7.3 & 4.8 & 6.1 & 4.4 & -5.0 & -0.5 & 2.9 & 3.0 & 2.5 & 2.6 \\
\hline Business investment & 5.2 & 5.6 & 8.5 & 6.5 & -5.9 & -0.6 & 4.0 & 4.0 & 3.3 & 3.3 \\
\hline Dwellings & 10.0 & 7.9 & 1.3 & 1.0 & -4.1 & -0.6 & 0.1 & 0.2 & 0.2 & 0.4 \\
\hline Public investment & 15.5 & -10.6 & 3.4 & -2.8 & -0.3 & 0.7 & 3.0 & 3.0 & 3.0 & 3.0 \\
\hline Stockbuilding $1 /$ & 0.3 & 0.8 & 0.1 & 0.4 & -0.3 & 0.3 & 0.0 & 0.0 & 0.0 & 0.0 \\
\hline Foreign balance 1/ & -0.6 & 0.0 & -0.3 & -1.0 & -0.6 & -0.1 & -0.2 & -1.0 & -0.3 & -0.5 \\
\hline Exports, goods and services & 3.9 & 2.7 & 3.9 & 2.7 & -1.5 & 1.1 & 1.4 & 2.0 & 2.8 & 3.1 \\
\hline Imports, goods and services & 4.9 & 2.7 & 4.4 & 4.0 & -0.9 & 1.3 & 1.7 & 3.2 & 3.1 & 3.6 \\
\hline Household saving ratio (in percent) & 12.2 & 12.3 & 11.9 & 14.1 & 14.5 & 14.4 & 14.2 & 14.1 & 14.1 & 14.0 \\
\hline Potential output growth & 1.9 & 1.9 & 1.8 & 1.7 & 1.6 & 1.5 & 1.4 & 1.4 & 1.3 & 1.2 \\
\hline Output gap (in percent) & -0.2 & 0.9 & 1.7 & 1.3 & -2.4 & -3.2 & -2.8 & -2.1 & -1.4 & -0.6 \\
\hline \multicolumn{11}{|l|}{ Employment } \\
\hline Unemployment rate & 8.5 & 8.3 & 7.5 & 6.9 & 8.7 & 9.3 & 8.8 & 8.5 & 8.2 & 7.5 \\
\hline NAIRU & 7.8 & 7.7 & 7.6 & 7.5 & 7.5 & 7.5 & 7.5 & 7.5 & 7.5 & 7.5 \\
\hline Employment & 1.3 & 1.4 & 1.5 & 1.4 & -1.8 & -0.2 & 1.2 & 0.9 & 1.1 & 1.5 \\
\hline \multicolumn{11}{|l|}{ Prices } \\
\hline Consumer prices & 2.5 & 2.3 & 1.8 & 4.5 & 0.9 & 1.5 & 1.9 & 1.9 & 2.0 & 2.0 \\
\hline GDP deflator & 2.5 & 2.3 & 2.4 & 2.1 & 1.9 & 2.0 & 2.1 & 2.2 & 2.2 & 2.0 \\
\hline \multirow[t]{2}{*}{ ULC (in whole economy) } & 1.0 & 1.3 & 3.0 & 3.7 & 1.8 & 2.3 & 2.6 & 2.5 & 2.5 & 2.5 \\
\hline & \multicolumn{10}{|c|}{ (In percent of GDP; unless otherwise indicated) } \\
\hline \multicolumn{11}{|l|}{ Public finance } \\
\hline Revenue & 49.3 & 48.6 & 48.1 & 48.7 & 48.6 & 48.6 & 48.5 & 48.5 & 48.4 & 48.2 \\
\hline Expenditure & 52.0 & 48.3 & 48.4 & 49.7 & 51.8 & 52.6 & 52.5 & 52.4 & 52.2 & 52.1 \\
\hline General government balance & -2.7 & 0.3 & -0.3 & -0.9 & -3.2 & -4.0 & -4.0 & -3.9 & -3.8 & -3.9 \\
\hline Structural balance & -0.1 & -0.2 & -0.3 & -0.5 & -1.4 & -1.8 & -2.0 & -2.3 & -2.5 & -2.6 \\
\hline Primary balance & 1.6 & 4.3 & 3.5 & 2.8 & 0.7 & 0.1 & 0.1 & 0.2 & 0.3 & 0.2 \\
\hline General government debt & 92.0 & 87.7 & 83.9 & 86.2 & 91.0 & 92.5 & 92.8 & 92.7 & 92.4 & 92.4 \\
\hline \multicolumn{11}{|l|}{ Balance of payments } \\
\hline Trade balance & 1.6 & 0.8 & 0.4 & -1.1 & -1.0 & -1.1 & -1.3 & -1.5 & -1.6 & -1.8 \\
\hline Current account & 2.6 & 2.6 & 2.1 & -2.1 & -2.0 & -2.1 & -2.2 & -2.3 & -2.4 & -2.5 \\
\hline Terms of Trade (percent change) & -0.9 & -1.0 & 0.0 & -0.2 & -0.1 & -0.2 & -0.2 & -0.1 & -0.1 & -0.2 \\
\hline \multicolumn{11}{|l|}{ Exports, goods and services } \\
\hline (volume, percent change) & 3.9 & 2.7 & 3.9 & 2.7 & -1.5 & 1.1 & 1.4 & 2.0 & 2.8 & 3.1 \\
\hline \multicolumn{11}{|l|}{ Imports, goods and services } \\
\hline (volume, percent change) & 4.9 & 2.7 & 4.4 & 4.0 & -0.9 & 1.3 & 1.7 & 3.2 & 3.1 & 3.6 \\
\hline
\end{tabular}

Sources: Data provided by the Belgian authorities, and IMF staff projections.

1/ Contribution to GDP growth. 
Table 2. Belgium: High-Frequency Financial Indicators

\begin{tabular}{|c|c|c|c|c|c|}
\hline & \multirow{3}{*}{$\begin{array}{r}1 / 12 / 09 \\
\text { Level } \\
\end{array}$} & \multicolumn{4}{|c|}{ Change since: } \\
\hline & & & & & \\
\hline & & $1 / 8 / 09$ & $1 / 5 / 09$ & $12 / 12 / 08$ & $1 / 11 / 08$ \\
\hline \multicolumn{6}{|c|}{ Financial institution equity prices $1 /$} \\
\hline Dexia & 3.4 & -3.7 & -2.3 & 1.9 & -81.5 \\
\hline Fortis & 1.3 & 15.6 & 28.4 & 40.4 & -92.5 \\
\hline KBC & 11.8 & -2.6 & -7.9 & -12.4 & -83.9 \\
\hline \multicolumn{6}{|l|}{ Credit default swap spreads $2 /$} \\
\hline Dexia & 285.5 & -9.5 & -23.1 & -38.3 & 227.0 \\
\hline Fortis & 137.6 & -1.6 & -26.2 & 12.0 & 70.9 \\
\hline KBC & 209.0 & 4.0 & -16.0 & -13.0 & 124.0 \\
\hline \multicolumn{6}{|l|}{ Stock indices $3 /$} \\
\hline BEL 20 & 1,971 & -0.3 & -1.7 & 6.2 & -51.0 \\
\hline Euro stoxx 50 & 2,452 & -2.6 & -4.0 & 1.4 & -42.0 \\
\hline \multicolumn{6}{|l|}{ Interbank interest rates 4/ } \\
\hline Overnight & 2.14 & -0.69 & -3.07 & -7.03 & -44.78 \\
\hline 3-month & 2.65 & -2.78 & -5.99 & -19.17 & -42.02 \\
\hline \multicolumn{6}{|l|}{ Government interest rates 4/ } \\
\hline 3-month & 1.49 & -8.59 & -12.87 & -21.58 & -61.99 \\
\hline 10-year & 3.88 & -1.65 & 1.94 & -5.32 & -9.28 \\
\hline Money market risk spread 5/ & 0.65 & 0.53 & 0.50 & 0.41 & -0.04 \\
\hline
\end{tabular}

Sources: Bloomberg; Datastream.

$1 /$ Euros; change in percentage points.

2/ Basis points, 5 Yr CDS.

$3 /$ Index; change in percentage points.

4/ Percent; change in percentage points.

5/ Basis points; 3-month interbank rate minus 3-month Treasury Bill. 
Table 3. Belgium: Fiscal Scenarios, 2004-14

(In percent of GDP, unadjusted for working days; unless otherwise indicated)

\begin{tabular}{|c|c|c|c|c|c|c|c|c|c|c|c|}
\hline & \multirow[b]{2}{*}{2004} & \multirow[b]{2}{*}{2005} & \multirow[b]{2}{*}{2006} & \multirow[b]{2}{*}{2007} & \multicolumn{6}{|c|}{ Projection } & \multirow[b]{2}{*}{2014} \\
\hline & & & & & 2008 & 2009 & 2010 & 2011 & 2012 & 2013 & \\
\hline \multicolumn{12}{|l|}{ Current policies (A) } \\
\hline Revenue & 49.2 & 49.3 & 48.6 & 48.1 & 48.7 & 48.6 & 48.6 & 48.5 & 48.5 & 48.4 & 48.2 \\
\hline Expenditure & 49.5 & 52.0 & 48.3 & 48.4 & 49.7 & 51.8 & 52.6 & 52.5 & 52.4 & 52.2 & 52.1 \\
\hline Primary expenditure & 44.7 & 47.7 & 44.4 & 44.5 & 45.8 & 48.0 & 48.5 & 48.4 & 48.3 & 48.1 & 48.0 \\
\hline Interest payments & 4.8 & 4.3 & 4.0 & 3.9 & 3.9 & 3.8 & 4.1 & 4.1 & 4.1 & 4.1 & 4.1 \\
\hline Balance 1/ & -0.3 & -2.7 & 0.3 & -0.3 & -0.9 & -3.2 & -4.0 & -4.0 & -3.9 & -3.8 & -3.9 \\
\hline Structural balance 2/ & -0.9 & -0.1 & -0.2 & -0.3 & -0.5 & -1.4 & -1.8 & -2.0 & -2.3 & -2.5 & -2.6 \\
\hline Balance change & -0.2 & -2.4 & 3.0 & -0.6 & -0.6 & -2.2 & -0.8 & 0.0 & 0.1 & 0.1 & -0.1 \\
\hline Change in structural balance & 0.2 & 0.8 & -0.1 & -0.1 & -0.2 & -0.9 & -0.4 & -0.2 & -0.2 & -0.2 & -0.1 \\
\hline Primary balance & 4.5 & 1.6 & 4.3 & 3.5 & 2.8 & 0.7 & 0.1 & 0.1 & 0.2 & 0.3 & 0.2 \\
\hline Structural primary balance 2/ & 3.9 & 4.2 & 3.8 & 3.6 & 3.4 & 2.4 & 2.3 & 2.1 & 1.8 & 1.6 & 1.4 \\
\hline Debt $1 /$ & 94.5 & 92.0 & 87.7 & 83.9 & 86.2 & 91.0 & 92.5 & 92.8 & 92.7 & 92.4 & 92.4 \\
\hline \multicolumn{12}{|l|}{ Memorandum items (in percent): } \\
\hline Real primary expenditure growth $2 /$ & 0.2 & 8.9 & -4.1 & 3.0 & 4.5 & 2.3 & 1.9 & 1.9 & 1.9 & 1.9 & 2.2 \\
\hline Real discretionary spending growth & -3.1 & 4.7 & 1.1 & 3.5 & 3.7 & 3.2 & 1.6 & 1.6 & 1.6 & 1.6 & 2.1 \\
\hline Output gap & -0.5 & -0.2 & 0.9 & 1.7 & 1.3 & -2.4 & -3.2 & -2.8 & -2.1 & -1.4 & -0.6 \\
\hline GDP growth & 2.8 & 2.2 & 3.0 & 2.6 & 1.3 & -2.1 & 0.8 & 2.0 & 2.2 & 2.3 & 2.3 \\
\hline \multicolumn{12}{|l|}{ Staff-recommended scenario (B) } \\
\hline Revenue & 49.2 & 49.3 & 48.6 & 48.1 & 48.7 & 48.6 & 48.6 & 48.5 & 48.5 & 48.4 & 48.2 \\
\hline Expenditure & 49.5 & 52.0 & 48.3 & 48.4 & 49.7 & 51.8 & 52.2 & 51.2 & 50.1 & 49.0 & 48.1 \\
\hline Primary expenditure & 44.7 & 47.7 & 44.4 & 44.5 & 45.8 & 48.0 & 48.2 & 47.2 & 46.2 & 45.2 & 44.4 \\
\hline Interest payments & 4.8 & 4.3 & 4.0 & 3.9 & 3.9 & 3.8 & 4.0 & 4.0 & 4.0 & 3.9 & 3.7 \\
\hline Balance 1/ & -0.3 & -2.7 & 0.3 & -0.3 & -0.9 & -3.2 & -3.6 & -2.7 & -1.7 & -0.6 & 0.1 \\
\hline Structural balance 2/ & -0.9 & -0.1 & -0.2 & -0.3 & -0.5 & -1.4 & -1.3 & -0.7 & 0.0 & 0.7 & 1.4 \\
\hline Balance change & -0.2 & -2.4 & 3.0 & -0.6 & -0.6 & -2.2 & -0.4 & 0.9 & 1.0 & 1.1 & 0.7 \\
\hline Change in structural balance & 0.2 & 0.8 & -0.1 & -0.1 & -0.2 & -0.9 & 0.0 & 0.7 & 0.7 & 0.7 & 0.7 \\
\hline Primary balance & 4.5 & 1.6 & 4.3 & 3.5 & 2.9 & 0.7 & 0.4 & 1.3 & 2.3 & 3.2 & 3.9 \\
\hline Structural primary balance 2/ & 3.9 & 4.2 & 3.8 & 3.6 & 3.4 & 2.4 & 2.7 & 3.3 & 3.9 & 4.5 & 5.1 \\
\hline Debt $1 /$ & 94.5 & 92.0 & 87.7 & 83.9 & 86.2 & 89.6 & 90.7 & 89.8 & 87.6 & 84.3 & 80.7 \\
\hline \multicolumn{12}{|l|}{ Memorandum items (in percent): } \\
\hline Real primary expenditure growth $2 /$ & 0.2 & 8.9 & -4.1 & 3.0 & 4.5 & 2.3 & 1.0 & 0.0 & 0.0 & 0.2 & 0.8 \\
\hline Output gap & -0.5 & -0.2 & 0.9 & 1.7 & 1.3 & -2.4 & -3.3 & -2.9 & -2.2 & -1.5 & -0.7 \\
\hline GDP growth & 2.8 & 2.2 & 3.0 & 2.6 & 1.3 & -2.1 & 0.6 & 1.9 & 2.2 & 2.4 & 2.6 \\
\hline
\end{tabular}

Sources: Data provided by the authorities; and IMF staff projections.

$1 /$ Includes the effect of the restructuring of the national railway company in 2005 as presented by Eurostat.

2/ Excludes one-off measures including the restructuring of the national railway company in 2005. 
Table 4. Belgium: Public Sector Debt Sustainability Framework, 2003-2013

(In percent of GDP, unless otherwise indicated)

\begin{tabular}{|c|c|c|c|c|c|c|c|c|c|c|c|c|c|c|}
\hline & \multicolumn{5}{|c|}{ Actual } & & & \multicolumn{6}{|c|}{ Projections } & \multirow{5}{*}{$\begin{array}{c}\text { Debt-stabilizing } \\
\text { primary } \\
\text { balance } 10 / \\
0.0\end{array}$} \\
\hline & 2003 & 2004 & 2005 & 2006 & 2007 & & & 2008 & 2009 & 2010 & 2011 & 2012 & 2013 & \\
\hline & & & & & & & & \multicolumn{6}{|c|}{ I. Baseline Projections } & \\
\hline Public sector debt $1 /$ & 98.7 & 94.5 & 92.0 & 87.7 & 83.9 & & & 86.2 & 91.0 & 92.5 & 92.8 & 92.7 & 92.4 & \\
\hline Of which: foreign-currency denominated & 1.4 & 0.8 & 0.8 & 0.7 & 0.5 & & & 0.5 & 0.5 & 0.6 & 0.6 & 0.6 & 0.6 & \\
\hline Change in public sector debt & -4.8 & -4.2 & -2.5 & -4.3 & -3.8 & & & 2.3 & 4.8 & 1.4 & 0.3 & -0.1 & -0.3 & \\
\hline Identified debt-creating flows $(4+7+12)$ & -2.9 & -4.7 & -1.6 & -4.9 & -3.9 & & & 2.3 & 4.8 & 1.3 & 0.2 & -0.2 & -0.4 & \\
\hline Primary deficit & -5.2 & -4.5 & -1.6 & -4.3 & -3.5 & & & -2.8 & -0.7 & -0.2 & -0.2 & -0.3 & -0.4 & \\
\hline Revenue and grants & 51.1 & 49.2 & 49.3 & 48.6 & 48.1 & & & 48.7 & 48.6 & 48.6 & 48.5 & 48.5 & 48.4 & \\
\hline Primary (noninterest) expenditure & 45.9 & 44.7 & 47.7 & 44.4 & 44.5 & & & 45.8 & 48.0 & 48.5 & 48.4 & 48.3 & 48.1 & \\
\hline Automatic debt dynamics $2 /$ & 2.3 & -0.2 & 0.1 & -0.7 & -0.4 & & & 0.9 & 4.0 & 1.5 & 0.3 & 0.1 & 0.0 & \\
\hline Contribution from interest rate/growth differential $3 /$ & 2.7 & -0.1 & 0.1 & -0.7 & -0.3 & & & 0.9 & 4.0 & 1.5 & 0.3 & 0.1 & 0.0 & \\
\hline Of which: contribution from real interest rate & 3.7 & 2.6 & 2.0 & 2.0 & 1.8 & & & 2.0 & 2.2 & 2.3 & 2.2 & 2.1 & 2.1 & \\
\hline Of which: contribution from real GDP growth & -1.0 & -2.6 & -2.0 & -2.6 & -2.2 & & & -1.0 & 1.8 & -0.7 & -1.8 & -2.0 & -2.1 & \\
\hline Contribution from exchange rate depreciation $4 /$ & -0.3 & -0.1 & 0.0 & 0.0 & -0.1 & & & 0.0 & 0.0 & 0.0 & 0.0 & 0.0 & 0.0 & \\
\hline Other identified debt-creating flows & 0.0 & 0.0 & 0.0 & 0.0 & 0.0 & & & 4.2 & 1.4 & 0.0 & 0.0 & 0.0 & 0.0 & \\
\hline Privatization receipts (negative) & 0.0 & 0.0 & 0.0 & 0.0 & 0.0 & & & 0.0 & 0.0 & 0.0 & 0.0 & 0.0 & 0.0 & \\
\hline Recognition of implicit or contingent liabilities & 0.0 & 0.0 & 0.0 & 0.0 & 0.0 & & & 0.0 & 0.0 & 0.0 & 0.0 & 0.0 & 0.0 & \\
\hline Other (specify, e.g. bank recapitalization) & 0.0 & 0.0 & 0.0 & 0.0 & 0.0 & & & 4.2 & 1.4 & 0.0 & 0.0 & 0.0 & 0.0 & \\
\hline Residual, including asset changes (2-3) & -1.9 & 0.5 & -1.0 & 0.6 & 0.2 & & & 0.1 & 0.0 & 0.1 & 0.1 & 0.1 & 0.1 & \\
\hline Public sector debt-to-revenue ratio 1 / & 193.2 & 191.9 & 186.6 & 180.3 & 174.6 & & & 177.0 & 187.2 & 190.4 & 191.3 & 191.3 & 190.8 & \\
\hline Gross financing need 5/ & 17.9 & 17.0 & 17.9 & 14.5 & 14.7 & & & 16.8 & 20.1 & 21.3 & 21.4 & 21.3 & 21.1 & \\
\hline In billions of U.S. dollars & 55.7 & 61.1 & 67.5 & 57.9 & 67.4 & $\begin{array}{c}10 \text {-Year } \\
\end{array}$ & 10-Year & 85.7 & 95.1 & 104.5 & 109.9 & 114.9 & 119.8 & \\
\hline Key Macroeconomic and Fiscal Assumptions & & & & & & $\begin{array}{l}\text { Historical } \\
\text { Average } \\
\end{array}$ & $\begin{array}{l}\text { Standard } \\
\text { Deviation } \\
\end{array}$ & & & & & & & $\begin{array}{c}\begin{array}{c}\text { Projected } \\
\text { Average }\end{array} \\
\end{array}$ \\
\hline Real GDP growth (in percent) & 1.0 & 2.8 & 2.2 & 3.0 & 2.6 & 2.3 & 1.0 & 1.3 & -2.1 & 0.8 & 2.0 & 2.2 & 2.3 & 1.1 \\
\hline Average nominal interest rate on public debt (in percent) $6 /$ & 5.3 & 5.1 & 4.8 & 4.6 & 4.6 & 5.5 & 0.7 & 4.6 & 4.4 & 4.6 & 4.6 & 4.6 & 4.6 & 4.6 \\
\hline Average real interest rate (nominal rate minus change & & & & & & & & & & & & & & \\
\hline in GDP deflator, in percent) & 3.7 & 2.8 & 2.3 & 2.3 & 2.3 & 3.6 & 1.1 & 2.5 & 2.5 & 2.6 & 2.5 & 2.4 & 2.4 & 2.5 \\
\hline Nominal appreciation (increase in US dollar value & & & & & & & & & & & & & & \\
\hline of local currency, in percent) & 19.7 & 9.9 & 0.2 & 0.8 & 9.2 & 2.3 & 9.2 & 7.3 & -6.8 & 0.7 & 0.6 & 0.5 & 0.5 & -0.9 \\
\hline Inflation rate (GDP deflator, in percent) & 1.6 & 2.3 & 2.5 & 2.3 & 2.4 & 1.9 & 0.6 & 2.1 & 1.9 & 2.0 & 2.1 & 2.2 & 2.2 & 2.1 \\
\hline Growth of real primary spending (deflated by GDP deflator, & & & & & & & & & & & & & & \\
\hline in percent) & 5.0 & 0.2 & 8.9 & -4.1 & 3.0 & 2.6 & 3.5 & 4.5 & 2.1 & 1.7 & 1.9 & 1.9 & 1.9 & 1.9 \\
\hline Primary deficit & -5.2 & -4.5 & -1.6 & -4.3 & -3.5 & -5.1 & 1.7 & -2.8 & -0.7 & -0.1 & -0.1 & -0.2 & -0.3 & -0.3 \\
\hline A. Alternative Scenarios & & & & & & & & \multicolumn{6}{|c|}{ II. Stress Tests for Public Debt Ratio } & $\begin{array}{c}\text { Debt-stabilizing } \\
\text { primary } \\
\text { balance 10/ }\end{array}$ \\
\hline A1. Key variables are at their historical averages in 2008-2013 7 I & & & & & & & & 86.2 & 83.6 & 79.6 & 75.6 & 71.4 & 67.2 & 0.8 \\
\hline A2. No policy change (constant primary balance) in $2008-2013$ & & & & & & & & 86.2 & 88.9 & 87.8 & 85.5 & 82.9 & 80.2 & 0.0 \\
\hline B. Bound Tests & & & & & & & & & & & & & & \\
\hline B1. Real interest rate is at baseline plus one standard deviations & & & & & & & & 86.2 & 91.5 & 93.4 & 94.2 & 94.5 & 94.7 & 0.5 \\
\hline B2. Real GDP growth is at baseline minus one-half standard deviation & & & & & & & & 86.2 & 91.7 & 94.1 & 95.6 & 96.9 & 98.2 & 0.5 \\
\hline B3. Primary balance is at baseline minus one-half standard deviation & & & & & & & & 86.2 & 91.9 & 94.1 & 95.3 & 96.1 & 96.5 & 0.0 \\
\hline B4. Combination of B1-B3 using one-quarter standard deviation shocks & & & & & & & & 86.2 & 91.9 & 94.3 & 95.5 & 96.4 & 97.0 & 0.5 \\
\hline B5. One time 30 percent real depreciation in 2009 9/ & & & & & & & & 86.2 & 91.2 & 92.6 & 92.9 & 92.7 & 92.3 & 0.0 \\
\hline B6. 10 percent of GDP increase in other debt-creating flows in 2009 & & & & & & & & 86.2 & 101.0 & 102.6 & 103.0 & 102.9 & 102.6 & 0.0 \\
\hline
\end{tabular}

1/ Indicate coverage of public sector, e.g., general government or nonfinancial public sector. Also whether net or gross debt is used.

$2 /$ Derived as $[(r-p(1+g)-g+a e(1+r)](1+g+p+g p))$ times previous period debt ratio, with $r=$ interest rate; $p=$ growth rate of GDP deflator; $g=$ real GDP growth rate; $a=$ share of foreign-currency denominated debt; and $e=$ nominal exchange rate depreciation (measured by increase in local currency value of U.S. dollar).

The eatnote $2 /$ as $r-\pi(1+g)$ and the real growth contribution as -9

$5 /$ Defined as public sector deficit, plus amortization of medium and long-term public sector debt, plus short-term debt at end of previous period.

6/ Derived as nominal interest expenditure divided by previous period debt stock.

7/ The key variables include real GDP growth; real interest rate, and primary balance in percent of GDP.

$8 /$ The implied change in other key variables under this scenario is discussed in the text.

$9 /$ Real depreciation is defined as nominal depreciation (measured by percentage fall in dollar value of local currency) minus domestic inflation (based on GDP deflator)

$10 /$ Assumes that key variables (real GDP growth, real interest rate, and other identified debt-creating flows) remain at the level of the last projection year. 
Table 5. Belgium: Financial Soundness Indicators of the Banking Sector, 2003-08 1/ (In percent)

\begin{tabular}{|c|c|c|c|c|c|c|}
\hline & 2003 & 2004 & 2005 & 2006 & 2007 & $2008(2)$ \\
\hline & \multicolumn{3}{|c|}{ Belgian GAAP } & \multicolumn{2}{|c|}{ IFRS } & \\
\hline \multicolumn{7}{|l|}{ Earnings and profitability } \\
\hline Return on assets & 0.4 & 0.5 & 0.5 & 0.7 & 0.4 & -1.0 \\
\hline Return on equity & 13.6 & 15.8 & 18.5 & 22.4 & 13.2 & -28.3 \\
\hline Net interest income to total income & 56.4 & 56.3 & 53.5 & 47.9 & 50.5 & 62.0 \\
\hline Interest margin & 1.1 & 1.0 & 0.9 & 0.9 & 0.8 & 0.9 \\
\hline Average yield on assets & 3.71 & 3.46 & 3.62 & 4.07 & 4.53 & 4.83 \\
\hline Average cost of funding & 2.58 & 2.42 & 2.68 & 3.20 & 3.78 & 3.98 \\
\hline Noninterest income to gross income & 43.6 & 43.7 & 46.5 & 52.1 & 49.5 & 38.0 \\
\hline o/w Net fee and commission income & 24.4 & 25.5 & 25.9 & 25.1 & 27.9 & 31.4 \\
\hline (Un)realised capital gains booked in P\&L & 10.1 & 8.9 & 8.2 & 14.6 & 14.3 & 3.4 \\
\hline Cost/income ratio & 73.9 & 72.0 & 72.6 & 55.7 & 61.1 & 71.1 \\
\hline Personnel expenses to noninterest expenses & 45.5 & 44.7 & 42.8 & 60.1 & 56.9 & 56.5 \\
\hline \multicolumn{7}{|l|}{ Structure assets } \\
\hline $\begin{array}{l}\text { Total assets (in percent of GDP) } \\
\text { o/w (in percent of total assets) }\end{array}$ & \multicolumn{5}{|c|}{ o/w (in percent of total assets) } & 480.2 \\
\hline Loans to credit institutions (3) & 20.0 & 18.6 & 20.3 & 20.1 & 20.3 & 17.5 \\
\hline Debt securities (3) & 27.4 & 25.5 & 23.4 & 22.5 & 18.8 & 18.1 \\
\hline Equity instruments (3) & 1.7 & 2.7 & 3.5 & 3.6 & 3.4 & 2.8 \\
\hline Derivatives (3) & 0.0 & 0.0 & 0.0 & 4.5 & 5.5 & 6.7 \\
\hline Loans to customers ( 3 ) & 41.5 & 42.2 & 43.2 & 41.6 & 42.2 & 43.0 \\
\hline \multirow{3}{*}{$\begin{array}{l}\text { o/w Belgian residents (in percent of loans) } \\
\text { Other EMU residents (in percent of loar } \\
\text { Rest of the World (in percent of loans) }\end{array}$} & 52 & 49 & 42 & 43 & 43 & 41 \\
\hline & 23 & 23 & 26 & 29 & 30 & 32 \\
\hline & 25 & 29 & 33 & 28 & 27 & 28 \\
\hline \multirow{2}{*}{$\begin{array}{l}\text { o/w Mortgage loans (in billion euro) } \\
\text { Consumer loans (in billion euro) }\end{array}$} & 117 & 132 & 155 & 190 & 208 & 210 \\
\hline & 14 & 13 & 14 & 15 & 17 & 19 \\
\hline o/w Term loans (in percent of loans) & 53.7 & 53.5 & 54.8 & 46.1 & 40.1 & 37.9 \\
\hline$o / w$. Reverse repo operations & $\ldots$ & $\ldots$ & $\ldots$ & 41.0 & 37.8 & 26.9 \\
\hline \multicolumn{7}{|l|}{ Funding and liquidity (in percent of total assets) } \\
\hline Debts to credit institutions & 24.9 & 24.6 & 30.1 & 29.2 & 27.4 & 27.0 \\
\hline Bank bonds and other debt securities & 11.2 & 10.0 & 8.7 & 11.2 & 11.3 & 10.8 \\
\hline Customer deposits & 40.3 & 39.9 & 36.7 & 39.1 & 37.9 & 38.4 \\
\hline o/w Sight deposits (3) & 13.7 & 13.4 & 13.5 & 11.1 & 11.9 & 10.6 \\
\hline Saving deposits (3) & 12.9 & 13.2 & 11.6 & 10.2 & 8.5 & 7.6 \\
\hline Term deposits (3) & 12.5 & 12.1 & 10.6 & 10.6 & 11.2 & 10.8 \\
\hline Retail deposits & $\ldots$ & $\ldots$ & $\ldots$ & 20.4 & 17.8 & 16.6 \\
\hline o/w Repo's & $\ldots$ & $\ldots$ & $\ldots$ & 13.5 & 11.7 & 14.1 \\
\hline Liquid assets (4) & 33 & 33 & 31 & 19 & 16 & 14 \\
\hline \multicolumn{7}{|l|}{ Asset quality } \\
\hline \multicolumn{7}{|l|}{ Sectoral distribution of loans } \\
\hline Credit institutions & $\ldots$ & $\ldots$ & $\ldots$ & 20.1 & 20.3 & 17.5 \\
\hline Corporate & $\ldots$ & $\ldots$ & $\ldots$ & 18.3 & 19.9 & 22.4 \\
\hline Retail & $\ldots$ & $\ldots$ & $\ldots$ & 18.3 & 17.5 & 17.3 \\
\hline Central governments & $\ldots$ & $\ldots$ & $\ldots$ & 0.8 & 1.0 & 1.1 \\
\hline Non-credit institutions & $\ldots$ & $\ldots$ & $\ldots$ & 4.1 & 3.8 & 2.3 \\
\hline Non-performing loans (NPL) as percent of gross loans (5) & 2.6 & 2.3 & 2.0 & 1.7 & 1.1 & 1.5 \\
\hline Provisions + writeoffs as percent of NPL (5) & 53 & 54 & 52 & 51 & 48 & 64 \\
\hline \multicolumn{7}{|l|}{ Capital adequacy } \\
\hline Regulatory capital to risk-weighted assets & 12.8 & 13.0 & 11.5 & 11.9 & 11.2 & 12.9 \\
\hline Regulatory Tier I capital to risk-weighted assets & 8.8 & 9.4 & 8.5 & 8.7 & 12.1 & 9.9 \\
\hline Capital to assets & 3.1 & 3.1 & 2.7 & 3.3 & 4.1 & 3.1 \\
\hline NPL net of provisions as percent of Tier I capital (5) & 15.7 & 12.8 & 13.8 & 10.9 & 9.2 & 17.4 \\
\hline Large exposures as percent of Tier I capital (5) & 46.0 & 40.0 & 42.5 & 36.2 & $\ldots$ & $\ldots$ \\
\hline Net open position in foreign exchange to capital & 7.0 & 5.3 & 5.8 & 6.4 & $\ldots$ & $\ldots$ \\
\hline
\end{tabular}
Source : CBFA and NBB.

(1) Consolidated data. Since 2006, the data are based on the IAS/IFRS reporting Scheme.

(2) Data for end-September 2008 of the first 9 months of 2008 . The flow data are annualised.

(3) Deposits booked at amortised cost only.

(4) As of 2006, liquid assets include cash and debt instruments issued by central government and financial institutions.

(5) Unconsolidated data. 
Table 6. Belgium: Financial Soundness Indicators of the Non-Banking Sectors, 2002-08 (In percent)

\begin{tabular}{|c|c|c|c|c|c|c|c|c|}
\hline & & 2002 & 2003 & 2004 & 2005 & 2006 & 2007 & 20082 \\
\hline \multicolumn{9}{|c|}{ Insurance sector $1 /$} \\
\hline Solvency & ratio & 254.1 & 248.4 & 250.7 & 258.8 & 252.6 & 224.6 & 200.9 \\
\hline \multicolumn{9}{|c|}{ Profitability $3 /$} \\
\hline & Return on equity ( $\%$, annualised) & -9.9 & 7.8 & 18.9 & 24.3 & 21.3 & 33.0 & 0.3 \\
\hline \multirow[t]{2}{*}{ Life } & Premiums (billion euro) & 14.4 & 17.6 & 20.0 & 25.2 & 20.4 & 21.9 & 20.8 \\
\hline & Technical result/premiums (\%) & -1.7 & 2.7 & 4.0 & 4.7 & 4.9 & 4.4 & -5.0 \\
\hline \multirow[t]{3}{*}{ Non-life } & Premiums (billion euro) & 8.5 & 9.1 & 9.6 & 8.9 & 9.3 & 9.3 & 9.6 \\
\hline & Combined ratio $(\%)$ & 111.6 & 102.1 & 99.6 & 104.3 & 101.7 & 102.1 & 102.0 \\
\hline & Technical result/premiums (\%) & -3.4 & 8.8 & 12.8 & 12.0 & 12.7 & 13.8 & 8.0 \\
\hline \multicolumn{9}{|c|}{ Corporate sector } \\
\hline Total deb & as a percentage of equity & 79.5 & 78.2 & 62.7 & 65.6 & 60.5 & 59.9 & $\ldots$ \\
\hline Profitabil & y (return on equity) & 11.7 & 12.9 & 10.3 & 10.8 & 9.6 & 9.8 & $\ldots$ \\
\hline Debt ser & ce coverage ratio & 176.7 & 195.6 & 185.9 & 194.5 & 152.5 & 162.8 & $\ldots$ \\
\hline \multicolumn{9}{|c|}{ Household sector 4 / } \\
\hline Debt (p.c & of GDP) & 41.4 & 42.3 & 42.9 & 45.2 & 48.1 & 50.1 & 50.1 \\
\hline Interest b & urden (p.c. disp. income) & 1.8 & 1.5 & 1.2 & 1.6 & 2.1 & 2.9 & 2.9 \\
\hline Financial & savings ratio (p.c. of GDP) & 5.1 & 4.9 & 3.6 & 4.2 & 3.6 & 4.9 & 1.4 \\
\hline Savings & & 15.8 & 14.7 & 13.3 & 12.6 & 12.9 & 13.7 & 12.9 \\
\hline \multicolumn{9}{|c|}{$\begin{array}{l}\text { Real estate sector } 4 / \\
\text { House price inflation }\end{array}$} \\
\hline & Houses & 8.2 & 6.6 & 10.3 & 18.1 & 11.3 & 9.8 & 3.9 \\
\hline & Apartments & 8.3 & 8.9 & 14.6 & 9.4 & 10.1 & 6.3 & 3.4 \\
\hline \multicolumn{2}{|c|}{ Mortgage loans as percent of total loans } & 22.3 & 27.6 & 27.4 & 26.2 & 34.0 & 32.7 & 29.6 \\
\hline \multirow{2}{*}{\multicolumn{2}{|c|}{$\begin{array}{l}\text { o/w Domestic households } \\
\text { Variable rate mortgages (p.c. of total new loans) }\end{array}$}} & 14.2 & 15.6 & 15.5 & 14.5 & 17.6 & 16.5 & 13.8 \\
\hline & & 12.3 & 25.9 & 53.3 & 36.3 & 7.4 & 1.2 & 2.5 \\
\hline
\end{tabular}

Source: NBB, Stadim, UPC.

1/ Unconsolidated data

2/ Provisional data for first 9 months of 2008, unless mentioned otherwise.

3/ Provisional 2008 figure for first 9 months (annualised).

4/ 2008 data are for the first half of the year. 


\section{ANNEX I. BELGIUM: FUND RELATIONS}

(As of December 31, 2008)

Mission: Brussels, December 4-15, 2008

Staff team: Messrs. Franks (Head), De Broeck, Ms. Yontcheva, and Mr. Jarmuzek (all EUR)

Country interlocutors: The prime minister, the vice-prime minister for the budget, the governor of the National Bank of Belgium, the director of the Treasury, the chairman of the Finance, Banking and Insurance Commission, the Head of the Federal Planning Bureau, the chairman of the public borrowing section of the High Finance Council, and their staffs; staff of the federal ministry of finance, the health care administration, the regional ministries of the budget for Flanders, Brussels and Wallonia, respectively; representatives of labor unions, employer organizations, and the financial sector. Mr. Kiekens (Executive Director) or Mr. Rottier (Advisor to the Executive Director) attended the meetings.

Fund relations: The previous Article IV consultation took place on March 21, 2008. The associated Executive Board's assessment is available at http://www.imf.org/external/np/sec/pn/2008/pn0840.htm and the staff report at http://www.imf.org/external/pubs/cat/longres.cfm?sk=21834.0. Belgium accepted the obligations under Article VIII and, apart from certain security restrictions, maintains an exchange system free of restrictions.

Data: Belgium subscribes to the Fund's Special Data Dissemination Standard, and comprehensive economic data are available on a timely basis (Appendix II).

I. Membership Status: Joined December 27, 1945; Article VIII

II. General Resources Account:

Quota

Fund holdings of currency

Reserve position in Fund

III. SDR Department:

Net cumulative allocation

Holdings

[Designation plan]

\section{SDR Million}

$4,605.20$

$3,967.85$

637.39

SDR Million

485.25

369.81

\section{Percent of Quota}

100.00

86.16

13.84

\section{Outstanding Purchases and Loans: None}


V. Latest Financial Arrangements: None

VI. Projected Payments to Fund (SDR million; based on existing use of resources and present holdings of SDRs):

Principal

Charges/interest

Total

\begin{tabular}{lllll}
\multicolumn{6}{c}{ Forthcoming } \\
\hline 2009 & 2010 & 2011 & 2012 & 2013
\end{tabular}

$\begin{array}{lllll}\frac{1.03}{1.03} & \underline{0.98} & \underline{0.98} & \underline{0.98} & \underline{0.98} \\ 0.98 & 0.98 & 0.98 & 0.98\end{array}$

\section{Article IV Consultations:}

Belgium is on the 12-month cycle; the last consultation was completed on March 21, 2008 (IMF Country Report No. 08/111).

\section{Exchange Rate Arrangements}

- $\quad$ Belgium's currency is the euro, which floats freely and independently against other currencies.

- $\quad$ Belgium maintains an exchange system free of restrictions on payments and transfers for current international transactions, except for restrictions maintained solely for security reasons. These measures are established by European Union regulations and have been notified to the Fund pursuant to Executive Board Decision No. 144-(52/51).

\section{FSAP Participation:}

\section{FSAP Assessment}

Summary: The report concluded that Belgium's financial system is resilient and benefits from a number of Belgium-specific features that help stability. These include a traditionally cautious attitude toward risk by banks, large holdings of government securities, extremely low holdings of equity by banks, a stable source of funding benefiting from generous tax incentives, a high standard of banking supervision, and a stable macroeconomic policy framework. Overall, supervision showed a high degree of compliance with international standards. Near-term vulnerability appears low, reflecting the soundness of the dominant banking system, the generally benign financial environment, the strong financial condition of the corporate sector, and the relatively healthy financial position of the household sector. Financial institutions were found to 
withstand an adverse macroeconomic stress well, helped in part by the beneficial diversification in the bancassurance model.

Notwithstanding the strengths of the Belgian financial sector, a number of issues emerged from the FSAP. The heavy exposure abroad, the open nature of the economy, and the importance of the Euroclear Group globally, made the domestic financial system potentially vulnerable to global economic developments and financial contagion. Risks remained and may increase with a downturn in the business cycle, increased cross-border operations, and deeper links with the global money centers. In line with the 2005 FSAP recommendations, the supervisory framework has been strengthened. The Banking, Finance, and Insurance Commission's (CBFA) management committee has been streamlined and synergies between the CBFA and the National Bank of Belgium (NBB) have been further developed. Regular stress tests have helped promote a systematic dialogue between supervisory authorities and market participants, while detailed procedures for financial crisis management have been tested. Prudential supervision of the insurance sector has been upgraded and regulation of the pension funds sector reinforced. 


\section{ANNEX II. BELGIUM: STATISTICAL ISSUES}

Belgium's economic and financial statistics are adequate for surveillance purposes. The National Bank of Belgium (NBB) regularly publishes a full range of economic and financial data and provides calendar dates of main statistical releases. On-line access to these comprehensive databases is facilitated by the NBB's data search engine, Belgostat. Belgium is a SDDS subscriber. Statistics for International Financial Statistics on banking institutions and monetary aggregates are prepared on a monthly basis and are timely.

Belgium adopted the European System of Integrated Economic Accounts 1995 (ESA95) in 1999. Revisions of national accounts started in November 2005 to comply with EUROSTAT requirements and prepare for the adoption of chain-linked national accounts statistics. Unlike in other countries, the NBB is responsible for compiling national accounts statistics. Quarterly accounts are published within a lag of three months. Both annual and quarterly accounts data are of good quality, with shortcomings mainly related to export and import deflators, which are based on unit values, rather than prices collected directly from exporters and importers.

General government revenue, expenditure, and balance on an accrual basis (ESA95) are published annually. The NBB publishes monthly data on central government operations and quarterly data on general government operations since April 2007.

The overall quality and availability of financial indicators are good. The authorities are providing quarterly updates of financial sector indicators (FSIs) in a timely manner.

Key publicly accessible websites for macroeconomic data and analysis are:

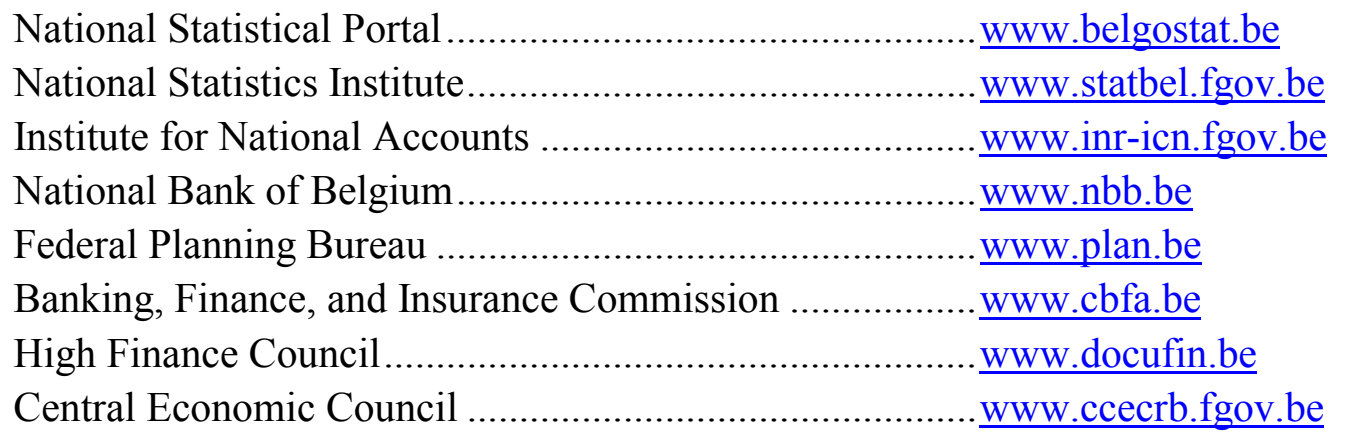




\section{BELGIUM: TABLE OF COMMON INDICATORS REQUIRED FOR SURVEILLANCE}

(As of February 17, 2009)

\begin{tabular}{|c|c|c|c|c|c|}
\hline & $\begin{array}{c}\text { Date of } \\
\text { Latest } \\
\text { Observation }\end{array}$ & $\begin{array}{c}\text { Date } \\
\text { Received }\end{array}$ & $\begin{array}{c}\text { Frequency } \\
\text { of } \\
\text { Data }^{6}\end{array}$ & $\begin{array}{c}\text { Frequency } \\
\text { of } \\
\text { Reporting }^{6}\end{array}$ & $\begin{array}{c}\text { Frequency } \\
\text { of } \\
\text { Publication }^{6}\end{array}$ \\
\hline Exchange Rates & 2/14/09 & 2/14/09 & $\mathrm{D}$ & $\mathrm{D}$ & $\mathrm{D}$ \\
\hline $\begin{array}{l}\text { International Reserve Assets and Reserve } \\
\text { Liabilities of the Monetary Authorities }{ }^{1}\end{array}$ & $11 / 08$ & $1 / 14 / 09$ & M & M & M \\
\hline Reserve/Base Money & $12 / 08$ & $1 / 09$ & M & M & M \\
\hline Broad Money & $12 / 08$ & $1 / 09$ & M & M & $\mathrm{M}$ \\
\hline Central Bank Balance Sheet & $12 / 08$ & $1 / 09$ & M & M & M \\
\hline $\begin{array}{l}\text { Consolidated Balance Sheet of the Banking } \\
\text { System }\end{array}$ & $12 / 08$ & $1 / 09$ & M & M & M \\
\hline Interest Rates ${ }^{2}$ & 2/14/09 & 2/14/09 & $\mathrm{D}$ & $\mathrm{D}$ & $\mathrm{D}$ \\
\hline Consumer Price Index & $12 / 08$ & $1 / 09$ & M & M & M \\
\hline $\begin{array}{l}\text { Revenue, Expenditure, Balance and } \\
\text { Composition of Financing }{ }^{3}-\text { General } \\
\text { Government }^{4}\end{array}$ & 2007 & $6 / 30 / 08$ & A & A & A \\
\hline $\begin{array}{l}\text { Revenue, Expenditure, Balance, and } \\
\text { Composition of Financing }{ }^{3} \text { - Central } \\
\text { Government }\end{array}$ & 2007 & $6 / 30 / 08$ & A & A & A \\
\hline $\begin{array}{l}\text { Stocks of Central Government and Central } \\
\text { Government-Guaranteed } \text { Debt }^{5}\end{array}$ & $12 / 08$ & $1 / 09$ & M & M & M \\
\hline External Current Account Balance & Q3 2008 & $12 / 08$ & Q & Q & Q \\
\hline $\begin{array}{l}\text { Exports and Imports of Goods and } \\
\text { Services }\end{array}$ & Q3 2008 & $12 / 08$ & Q & Q & Q \\
\hline GDP/GNP & Q3 2008 & $12 / 08$ & Q & Q & Q \\
\hline Gross External Debt & Q3 2008 & $12 / 08$ & Q & Q & Q \\
\hline
\end{tabular}

${ }^{1}$ Includes reserve assets pledged or otherwise encumbered as well as net derivative positions.

${ }^{2}$ Both market-based and officially-determined, including discount rates, money market rates, rates on treasury bills, notes and bonds.

${ }^{3}$ Foreign, domestic bank, and domestic nonbank financing.

${ }^{4}$ The general government consists of the central government (budgetary funds, extra budgetary funds, and social security funds) and state and local governments.

${ }^{5}$ Including currency and maturity composition.

${ }^{6}$ Daily (D), weekly (W), monthly (M), quarterly (Q), annually (A), irregular (I); and not available (NA). 
INTERNATIONAL MONETARY FUND

BELGIUM

\title{
Staff Report for the 2008 Article IV Consultation Supplementary Information
}

\author{
Prepared by the European Department \\ (In consultation with the Strategy, Policy, and Review Department) \\ Approved by Ajai Chopra and Anthony Boote
}

March 2, 2009

This supplement to the staff report for the 2008 Article IV consultation with Belgium provides an update on the staff's revised economic outlook, recent developments in financial markets, and the 2009 budget and economic stimulus package. The information does not alter the thrust of the staff appraisal.

\section{Summary}

GDP is forecast to contract by 2.5 percent in 2009 due to deeper recessions in partner countries, a worse outcome than anticipated in the staff report. The financial sector faces increased risks related to adverse developments in central and Eastern Europe as well as legal proceedings. Reflecting the downward revision of the growth forecast, the general government deficit is now projected to widen to 3.4 percent from 3.2 percent in the staff report.

\section{Outlook}

1. Staff projects the real GDP contraction to deepen to 2.5 percent in 2009 , from 1.9 percent in the staff report (Table 1). The revision is driven by worse-than-anticipated growth results for the last quarter of 2008 and reflects downward revisions to the growth outlook in Belgium's main economic partners. Consumer and business confidence further eroded in February 2009 as labor market conditions are deteriorating. In addition, significant downside risks remain, related to the international environment and contagion effects from the global financial crisis.

\section{Financial sector}

2. The need for additional interventions in the financial sector cannot be ruled out. The shareholders' rejection of the sale of Fortis Bank Belgium to BNP-Paribas has 
heightened uncertainties about the future of the group, and has exposed the budget and Belgium's sovereign rating to additional risk. The recent sharp drop in KBC's share price and jump in its credit default spread manifest market uneasiness about the group's core capital ratio and its exposure to emerging Europe where vulnerabilities have risen. The liquidity position of the third major Belgian bankassurance group, Dexia, remains severely mismatched, and the group might need to shore up its capital. As the need for additional government support to these and other financial institutions cannot be excluded, establishing a broader intervention framework remains a priority.

\section{9 budget and stimulus plan}

The government has updated its fiscal projections to take into account the deterioration in the economic parameters underlying the budget and the Plan de Relance's measures. The general government deficit is now officially projected to widen to 3.4 percent of GDP in 2009. At this stage, the government is not considering any additional measures beyond the ones contained in the 2009 budget and in the Plan de Relance, which is still being debated by parliament. The government intends to return to a medium-term fiscal consolidation strategy as soon as economic conditions allow it, and has tasked the High Finance Council with quantifying adjustment objectives. 
Table 1. Belgium: Selected Economic Indicators 2005-14

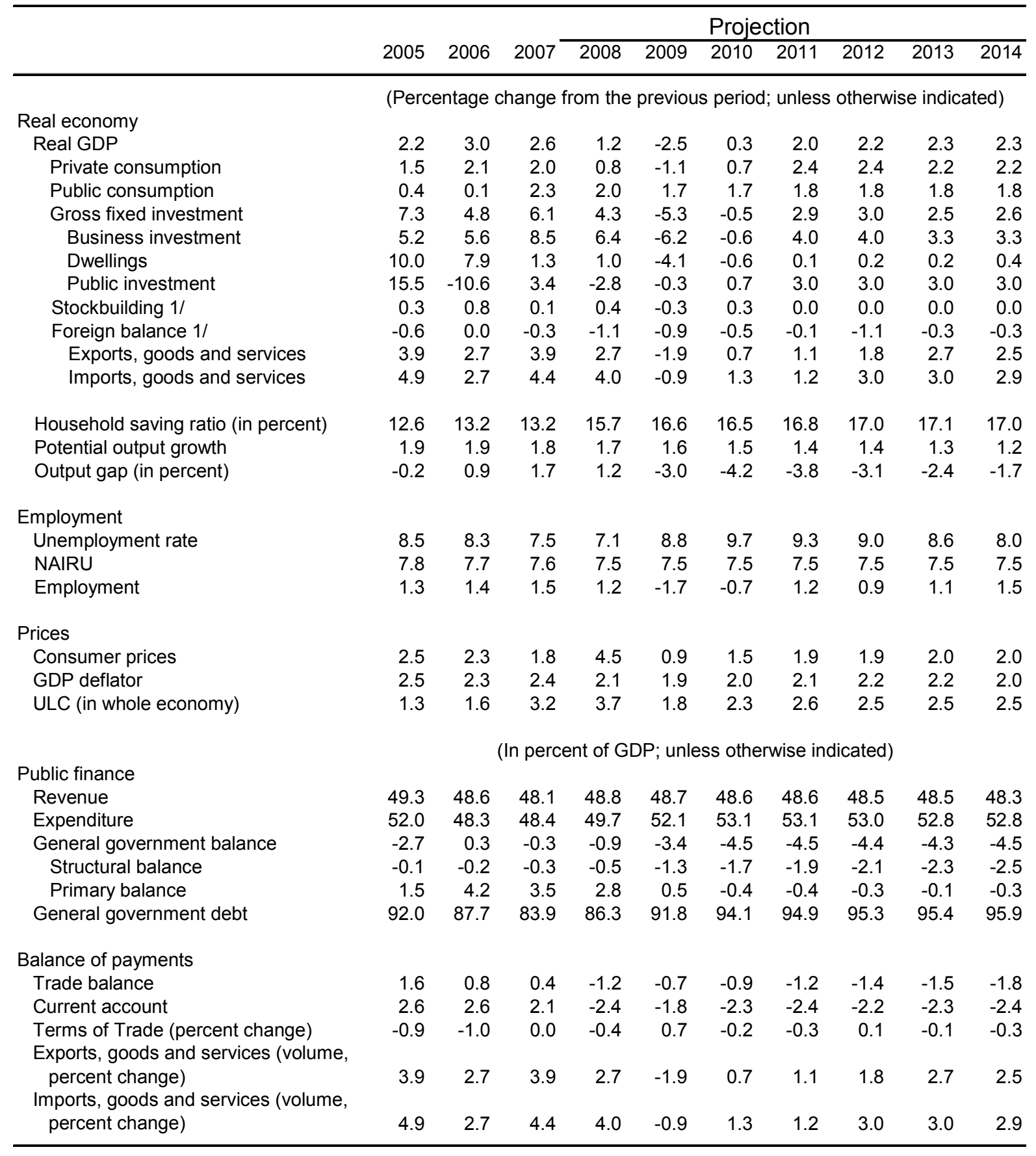

Sources: Data provided by the Belgian authorities, and IMF staff projections.

1/ Contribution to GDP growth. 
Table 2. Belgium: Fiscal Scenarios, 2004-14

(In percent of GDP, unadjusted for working days; unless otherwise indicated)

\begin{tabular}{|c|c|c|c|c|c|c|c|c|c|c|c|}
\hline & & & & & & & Projec & ion & & & \\
\hline & 2004 & 2005 & 2006 & $2007^{-7}$ & 2008 & 2009 & 2010 & 2011 & 2012 & 2013 & 2014 \\
\hline Current policies (A) & & & & & & & & & & & \\
\hline Revenue & 49.2 & 49.3 & 48.6 & 48.1 & 48.8 & 48.7 & 48.6 & 48.6 & 48.5 & 48.5 & 48.3 \\
\hline Expenditure & 49.5 & 52.0 & 48.3 & 48.4 & 49.7 & 52.1 & 53.1 & 53.1 & 53.0 & 52.8 & 52.8 \\
\hline Primary expenditure & 44.7 & 47.7 & 44.4 & 44.5 & 45.9 & 48.2 & 49.0 & 49.0 & 48.8 & 48.6 & 48.6 \\
\hline Interest payments & 4.8 & 4.3 & 4.0 & 3.9 & 3.9 & 3.8 & 4.1 & 4.2 & 4.2 & 4.2 & 4.2 \\
\hline Balance 1/ & -0.3 & -2.7 & 0.3 & -0.3 & -0.9 & -3.4 & -4.5 & -4.5 & -4.4 & -4.3 & -4.5 \\
\hline Structural balance 2/ & -0.9 & -0.1 & -0.2 & -0.3 & -0.4 & -1.3 & -1.7 & -2.0 & -2.3 & -2.5 & -2.7 \\
\hline Balance change & -0.2 & -2.4 & 3.0 & -0.6 & -0.6 & -2.4 & -1.1 & 0.0 & 0.1 & 0.1 & -0.1 \\
\hline Change in structural balance & 0.2 & 0.8 & -0.1 & -0.1 & -0.1 & -0.9 & -0.5 & -0.3 & -0.3 & -0.3 & -0.1 \\
\hline Primary balance & 4.5 & 1.6 & 4.3 & 3.5 & 2.8 & 0.5 & -0.4 & -0.4 & -0.3 & -0.1 & -0.3 \\
\hline Structural primary balance $2 /$ & 3.9 & 4.2 & 3.8 & 3.6 & 3.5 & 2.5 & 2.4 & 2.1 & 1.9 & 1.7 & 1.5 \\
\hline Debt $1 /$ & 94.5 & 92.0 & 87.8 & 83.9 & 86.3 & 91.8 & 94.1 & 94.9 & 95.3 & 95.4 & 95.9 \\
\hline Memorandum items (in percent): & & & & & & & & & & & \\
\hline Real primary expenditure growth $2 /$ & 0.2 & 8.9 & -4.1 & 3.0 & 4.5 & 2.3 & 1.9 & 1.9 & 1.9 & 1.9 & 2.2 \\
\hline Real discretionary spending growth $2 /$ & -3.1 & 4.7 & 1.1 & 3.5 & 3.7 & 3.2 & 1.6 & 1.6 & 1.6 & 1.6 & 2.1 \\
\hline Output gap & -0.5 & -0.2 & 0.9 & 1.7 & 1.2 & -3.0 & -4.2 & -3.8 & -3.1 & -2.4 & -1.7 \\
\hline GDP growth & 2.8 & 2.2 & 3.0 & 2.6 & 1.2 & -2.5 & 0.3 & 2.0 & 2.2 & 2.3 & 2.3 \\
\hline Staff-recommended scenario (B) & & & & & & & & & & & \\
\hline Revenue & 49.2 & 49.3 & 48.6 & 48.1 & 48.8 & 48.7 & 48.6 & 48.6 & 48.5 & 48.5 & 48.3 \\
\hline Expenditure & 49.5 & 52.0 & 48.3 & 48.4 & 49.7 & 52.1 & 52.7 & 51.8 & 50.7 & 49.6 & 48.7 \\
\hline Primary expenditure & 44.7 & 47.7 & 44.4 & 44.5 & 45.9 & 48.2 & 48.7 & 47.7 & 46.7 & 45.7 & 44.8 \\
\hline Interest payments & 4.8 & 4.3 & 4.0 & 3.9 & 3.9 & 3.8 & 4.1 & 4.1 & 4.0 & 4.0 & 3.8 \\
\hline Balance 1/ & -0.3 & -2.7 & 0.3 & -0.3 & -0.9 & -3.4 & -4.1 & -3.2 & -2.2 & -1.1 & -0.4 \\
\hline Structural balance $2 /$ & -0.9 & -0.1 & -0.2 & -0.3 & -0.4 & -1.3 & -1.3 & -0.7 & 0.0 & 0.7 & 1.4 \\
\hline Balance change & -0.2 & -2.4 & 3.0 & -0.6 & -0.6 & -2.4 & -0.7 & 0.9 & 1.0 & 1.1 & 0.7 \\
\hline Change in structural balance & 0.2 & 0.8 & -0.1 & -0.1 & -0.1 & -0.9 & -0.1 & 0.7 & 0.7 & 0.7 & 0.7 \\
\hline Primary balance & 4.5 & 1.6 & 4.3 & 3.5 & 2.9 & 0.5 & 0.0 & 0.9 & 1.9 & 2.8 & 3.5 \\
\hline Structural primary balance 2/ & 3.9 & 4.2 & 3.8 & 3.6 & 3.5 & 2.5 & 2.8 & 3.4 & 4.1 & 4.6 & 5.3 \\
\hline Debt 1/ & 94.5 & 92.0 & 87.8 & 83.9 & 86.3 & 90.3 & 92.3 & 91.8 & 90.1 & 87.2 & 84.0 \\
\hline Memorandum items (in percent): & & & & & & & & & & & \\
\hline Real primary expenditure growth $2 /$ & 0.2 & 8.9 & -4.1 & 3.0 & 4.5 & 2.3 & 1.0 & 0.0 & 0.0 & 0.2 & 0.8 \\
\hline Output gap & -0.5 & -0.2 & 0.9 & 1.7 & 1.2 & -3.0 & -4.3 & -3.9 & -3.2 & -2.5 & -1.8 \\
\hline GDP growth & 2.8 & 2.2 & 3.0 & 2.6 & 1.2 & -2.5 & 0.1 & 1.9 & 2.2 & 2.4 & 2.6 \\
\hline
\end{tabular}

Sources: Data provided by the authorities; and IMF staff projections.

$1 /$ Includes the effect of the restructuring of the national railway company in 2005 as presented by Eurostat.

2/ Excludes one-off measures including the restructuring of the national railway company in 2005. 


\section{INTERNATIONAL MONETARY FUND}

EXTERNAL

Public Information Notice

RELATIONS

DEPARTMENT

Public Information Notice (PIN) No. 09/32

FOR IMMEDIATE RELEASE

March 10, 2009

International Monetary Fund

$70019^{\text {th }}$ Street, NW

Washington, D. C. 20431 USA

\section{IMF Executive Board Concludes 2008 Article IV Consultation with Belgium}

On March 4, 2009, the Executive Board of the International Monetary Fund (IMF) concluded the Article IV consultation with Belgium. ${ }^{1}$

\section{Background}

The global financial crisis has hit the country particularly hard in recent months, forcing government intervention in major financial institutions. The boom in energy and food prices in early 2008 caused inflation to spike to well above the euro area average, posing risks to competitiveness while uncovering fault lines in domestic price-setting mechanisms and sparking concerns over retail competition. In addition, political uncertainty is high, complicating prospects for decisive action to address the economic difficulties.

Looking ahead, staff expects a deep recession in 2009, with a sluggish recovery in 2010 as the rebound in the world economy will be slowed by the aftermath of the financial crisis. Greater economic uncertainty and less favorable financing conditions will lower business investment, and consumption will decelerate in response to more sluggish real disposable income growth and job losses. Spillovers from the global financial turmoil and recessions in partner countries will exert an additional drag on activity. Concerns about the depth and persistence of the ongoing financial market turmoil and its effects on growth constitute downside risks.

\footnotetext{
${ }^{1}$ Under Article IV of the IMF's Articles of Agreement, the IMF holds bilateral discussions with members, usually every year. A staff team visits the country, collects economic and financial information, and discusses with officials the country's economic developments and policies. On return to headquarters, the staff prepares a report, which forms the basis for discussion by the Executive Board. At the conclusion of the discussion, the Managing Director, as Chairman of the Board, summarizes the views of Executive Directors, and this summary is transmitted to the country's authorities.
} 
Fuelled by increases in world energy and commodity prices, Belgian headline inflation peaked at 5.9 percent, year-on-year, in July, 2008, almost 2 percentage points above the euro area average. This spike has now begun to reverse, but the aftereffects will continue to be felt in 2009. Inflation should fall to around 2 percent in 2009, but may still remain above the euro area average. Indexation mechanisms will generate higher wage growth than in partner countries over the coming year, which will help sustain demand but also contribute to a continued decline in external competitiveness. The recent inflation dynamics have also highlighted structural concerns about price-setting in food and energy markets.

Belgium's financial sector weathered the early rounds of financial turmoil in 2007, but succumbed in September-October 2008. The system's strong capitalization and moderate exposure to subprime risk appeared to confer relative resilience when the 2007 liquidity shock broke. However, tighter world liquidity conditions in the wake of the Lehman collapse, together with specific concerns about Fortis and Dexia banks, triggered a crisis in September 2008. As world financial conditions turned increasingly desperate, the authorities were forced to intervene in all three major Belgian banks and in an insurance company.

The implementation of the 2008 federal budget was delayed by the lack of a government, and its consolidation effort was less ambitious than originally envisaged. Fiscal policy in 2009 allows for full operation of the automatic stabilizers, plus a moderate discretionary stimulus (around 1 percent of GDP), which will widen the general government deficit to beyond 3 percent of GDP. As an anchor to fiscal policy and to ensure fiscal sustainability, the government should firmly commit now to a structural adjustment of a least 0.7 percent of GDP per year once the crisis has past.

\section{Executive Board Assessment}

Executive Directors noted that, as a small open economy, Belgium has been severely affected by the global financial crisis and economic slowdown, as well as the earlier commodity and oil price shocks. They commended the authorities for their prompt and decisive intervention as the Belgian banking sector began to face severe pressure in September 2008. On the fiscal side, Directors concurred that it will be essential to strike the right balance between the need for short-term stimulus and achieving medium-term fiscal sustainability, given the relatively high debt level and the aging population. Directors were of the view that at this stage there is no room for additional fiscal stimulus measures.

Directors noted that the near-term economic outlook is bleak. With a protracted global financial crisis and recessions in partner countries, GDP growth is expected to contract sharply in 2009 and to recover only sluggishly in 2010 , with significant downside risks. Acknowledging that the current conjuncture presents significant policy challenges, Directors encouraged the authorities to allow fiscal stabilizers to operate fully, and welcomed the moderate discretionary stimulus. They noted, however, that to be effective, the stimulus measures need to be timely, targeted, and temporary, and should be tied to structural fiscal improvements aimed at ensuring longerterm sustainability. Directors encouraged the authorities to adopt a strong and credible program of medium-term fiscal consolidation. 
Directors welcomed the government's initial intervention in the banking sector, and noted that the need for further intervention could not be ruled out. They called for the authorities to establish a comprehensive framework for future interventions, in line with the framework agreed at the EU level.

Directors agreed that the rapid expansion of some Belgian banks in emerging market economies had been beneficial for both Belgium and the host countries. At the same time, these increased interlinkages call for strong and effective cross-border cooperation between supervisors. Directors recommended strengthening existing venues such as supervisory colleges and bilateral memoranda of understanding, with some Directors suggesting consideration for expanding pan-European supervisory mechanisms.

Looking beyond the current crisis, Directors encouraged the authorities to tackle longstanding structural weaknesses, particularly in light of Belgium's inflation differentials with its European partner countries and relatively high labor costs. To ease structural rigidities, boost growth, facilitate job creation, and help reverse the deterioration of Belgium's competitive position in the world, they recommended reinforcing the competition authority, liberalizing product and service markets, and reviewing the price-setting mechanism in energy supply and distribution. Directors encouraged the authorities to press ahead with labor market reforms so as to boost participation rates and reduce unemployment. They also advised considering a revision of the wage indexation mechanisms within the centralized bargaining framework. Consideration should also be given to reforming the current fiscal federalism framework to improve its efficiency and effectiveness, with a view to providing a better match between spending authority and revenueraising responsibilities.

Public Information Notices (PINs) form part of the IMF's efforts to promote transparency of the IMF's views and analysis of economic developments and policies. With the consent of the country (or countries) concerned, PINs are issued after Executive Board discussions of Article IV consultations with member countries, of its surveillance of developments at the regional level, of post-program monitoring, and of ex post assessments of member countries with longer-term program engagements. PINs are also issued after Executive Board discussions of general policy matters, unless otherwise decided by the Executive Board in a particular case. The staff report (use the free Adobe Acrobat Reader to view this pdf file) for the 2008 Article IV Consultation with Belgium is also available. 


\begin{tabular}{|c|c|c|c|c|c|c|}
\hline \multicolumn{7}{|c|}{ Belgium: Selected Economic Indicators 2005-10 } \\
\hline & & & & & & \\
\hline & & & & \multicolumn{3}{|c|}{ Projections } \\
\hline & 2005 & 2006 & 2007 & 2008 & 2009 & 2010 \\
\hline \multicolumn{7}{|c|}{ (Percentage change from the previous period; unless otherwise indicated) } \\
\hline \multicolumn{7}{|l|}{ Real economy } \\
\hline Real GDP & 2.2 & 3.0 & 2.6 & 1.2 & -2.5 & 0.3 \\
\hline Private consumption & 1.5 & 2.1 & 2.0 & 0.8 & -1.1 & 0.7 \\
\hline Public consumption & 0.4 & 0.1 & 2.3 & 2.0 & 1.7 & 1.7 \\
\hline Gross fixed investment & 7.3 & 4.8 & 6.1 & 4.3 & -5.3 & -0.5 \\
\hline Business investment & 5.2 & 5.6 & 8.5 & 6.4 & -6.2 & -0.6 \\
\hline Dwellings & 10.0 & 7.9 & 1.3 & 1.0 & -4.1 & -0.6 \\
\hline Public investment & 15.5 & -10.6 & 3.4 & -2.8 & -0.3 & 0.7 \\
\hline Stockbuilding 1/ & 0.3 & 0.8 & 0.1 & 0.4 & -0.3 & 0.3 \\
\hline Foreign balance 1/ & -0.6 & 0.0 & -0.3 & -1.1 & -0.9 & -0.5 \\
\hline Exports, goods and services & 3.9 & 2.7 & 3.9 & 2.7 & -1.9 & 0.7 \\
\hline Imports, goods and services & 4.9 & 2.7 & 4.4 & 4.0 & -0.9 & 1.3 \\
\hline Household saving ratio (in percent) & 12.6 & 13.2 & 13.2 & 15.7 & 16.6 & 16.5 \\
\hline Potential output growth & 1.9 & 1.9 & 1.8 & 1.7 & 1.6 & 1.5 \\
\hline Output gap (in percent) & -0.2 & 0.9 & 1.7 & 1.2 & -3.0 & -4.2 \\
\hline \multicolumn{7}{|l|}{ Employment } \\
\hline Unemployment rate & 8.5 & 8.3 & 7.5 & 7.1 & 8.8 & 9.7 \\
\hline NAIRU & 7.8 & 7.7 & 7.6 & 7.5 & 7.5 & 7.5 \\
\hline Employment & 1.3 & 1.4 & 1.5 & 1.2 & -1.7 & -0.7 \\
\hline \multicolumn{7}{|l|}{ Prices } \\
\hline Consumer prices & 2.5 & 2.3 & 1.8 & 4.5 & 0.9 & 1.5 \\
\hline GDP deflator & 2.5 & 2.3 & 2.4 & 2.1 & 1.9 & 2.0 \\
\hline \multirow[t]{2}{*}{ ULC (in whole economy) } & 1.3 & 1.6 & 3.2 & 3.7 & 1.8 & 2.3 \\
\hline & \multicolumn{6}{|c|}{ (In percent of GDP; unless otherwise indicated) } \\
\hline \multicolumn{7}{|l|}{ Public finance } \\
\hline Revenue & 49.3 & 48.6 & 48.1 & 48.8 & 48.7 & 48.6 \\
\hline Expenditure & 52.0 & 48.3 & 48.4 & 49.7 & 52.1 & 53.1 \\
\hline General government balance & -2.7 & 0.3 & -0.3 & -0.9 & -3.4 & -4.5 \\
\hline Structural balance & -0.1 & -0.2 & -0.3 & -0.5 & -1.3 & -1.7 \\
\hline Primary balance & 1.5 & 4.2 & 3.5 & 2.8 & 0.5 & -0.4 \\
\hline General government debt & 92.0 & 87.7 & 83.9 & 86.3 & 91.8 & 94.1 \\
\hline \multicolumn{7}{|l|}{ Balance of payments } \\
\hline Trade balance & 1.6 & 0.8 & 0.4 & -1.2 & -0.7 & -0.9 \\
\hline Current account & 2.6 & 2.6 & 2.1 & -2.4 & -1.8 & -2.3 \\
\hline Terms of Trade (percent change) & -0.9 & -1.0 & 0.0 & -0.4 & 0.7 & -0.2 \\
\hline $\begin{array}{l}\text { Exports, goods and services } \\
\text { (volume, percent change) }\end{array}$ & 3.9 & 2.7 & 3.9 & 2.7 & -1.9 & 0.7 \\
\hline $\begin{array}{l}\text { Imports, goods and services } \\
\text { (volume, percent change) }\end{array}$ & 4.9 & 2.7 & 4.4 & 4.0 & -0.9 & 1.3 \\
\hline
\end{tabular}

